\title{
Dental pulp stem cell-derived exosomes suppress M1 macrophage polarization through the ROS-MAPK-NFKB P65 signaling pathway after spinal cord injury
}

\author{
Chao Liu' ${ }^{1}$ Fanqi Hu², Genlong Jiao ${ }^{1}$, Yue Guo ${ }^{1}$, Pan Zhou', Yuning Zhang ${ }^{3}$, Zhen Zhang ${ }^{2}$, Jing Yi ${ }^{3}$,
} Yonggang You ${ }^{1,3}$, Zhizhong $\mathrm{Li}^{1^{*}}$, Hua Wang ${ }^{3^{*}}$ and Xuesong Zhang ${ }^{2^{*}}$

\begin{abstract}
Stem cell-derived exosomes have recently been regarded as potential drugs for treating spinal cord injury (SCI) by reducing reactive oxygen species (ROS) and suppressing M1 macrophage polarization. However, the roles of ROS and exosomes in the process of M1 macrophage polarization are not known. Herein, we demonstrated that ROS can induce M1 macrophage polarization and have a concentration-dependent effect. ROS can induce M1 macrophage polarization through the MAPK-NFKB P65 signaling pathway. Dental pulp stem cell (DPSC)-derived exosomes can reduce macrophage M1 polarization through the ROS-MAPK-NFKB P65 signaling pathway in treating SCI. This study suggested that DPSC-derived exosomes might be a potential drug for treating SCl. Disruption of the cycle between $\mathrm{ROS}$ and M1 macrophage polarization might also be a potential effective treatment by reducing secondary damage.
\end{abstract}

\footnotetext{
*Correspondence: lizhizhongjd1@163.com; 18511712135@163.com; zhangxuesong301@126.com

${ }^{1}$ Department of Orthopaedics, The First Affiliated Hospital of Jinan University, Huangpu Avenue West Road, Guangzhou, People's Republic of China

${ }^{2}$ Department of Orthopaedics, Chinese People's Liberation Army General

Hospital, Beijing, People's Republic of China

${ }^{3}$ Beijing Institute of Radiation Medicine, Beijing, People's Republic

of China
}

(c) The Author(s) 2022. Open Access This article is licensed under a Creative Commons Attribution 4.0 International License, which permits use, sharing, adaptation, distribution and reproduction in any medium or format, as long as you give appropriate credit to the original author(s) and the source, provide a link to the Creative Commons licence, and indicate if changes were made. The images or other third party material in this article are included in the article's Creative Commons licence, unless indicated otherwise in a credit line to the material. If material is not included in the article's Creative Commons licence and your intended use is not permitted by statutory regulation or exceeds the permitted use, you will need to obtain permission directly from the copyright holder. To view a copy of this licence, visit http://creativecommons.org/licenses/by/4.0/. The Creative Commons Public Domain Dedication waiver (http://creativeco mmons.org/publicdomain/zero/1.0/) applies to the data made available in this article, unless otherwise stated in a credit line to the data. 


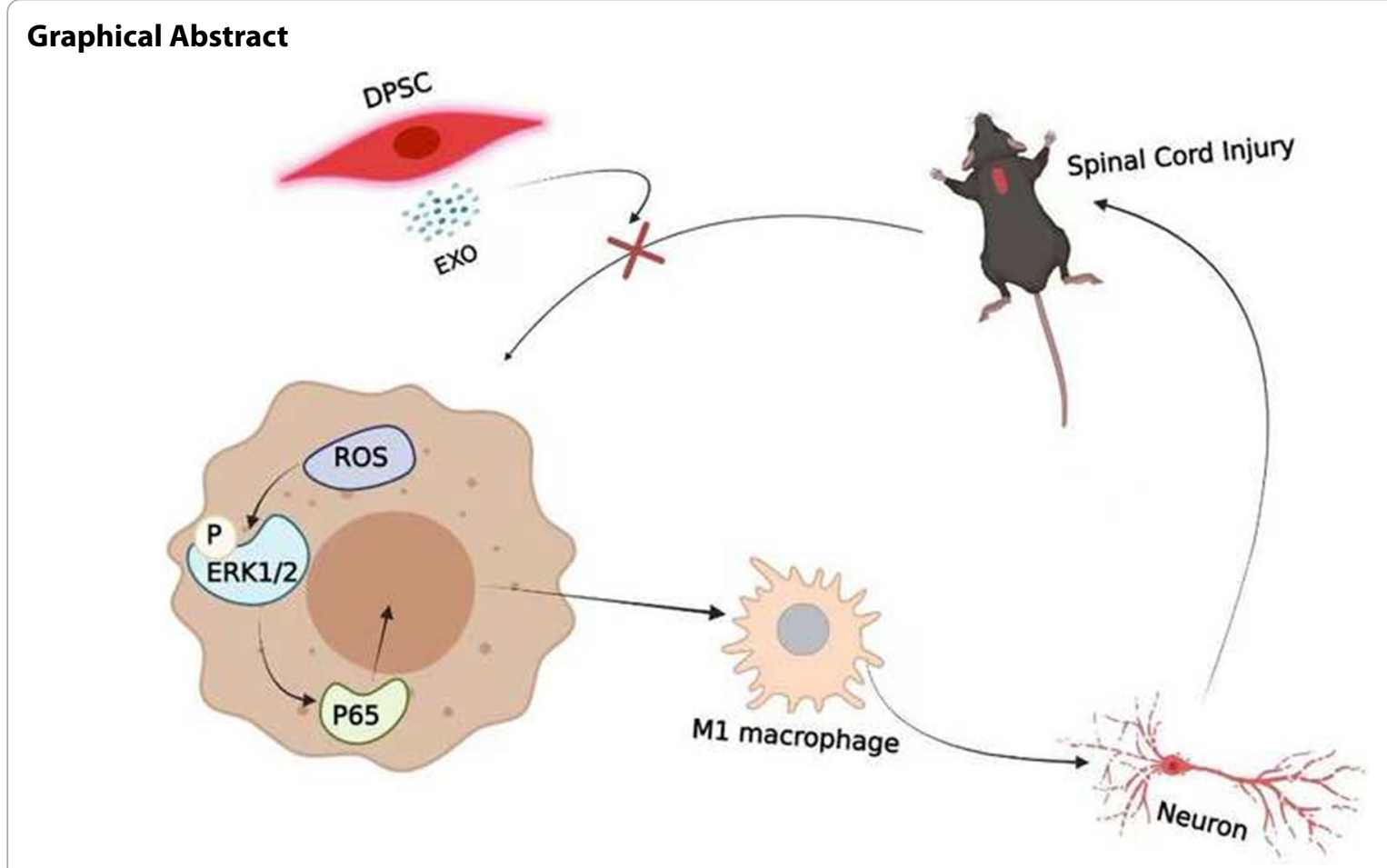

\section{Introduction}

Spinal cord injury (SCI) is a complex and devastating clinical condition characterized by deleterious functional loss of sensory and motor functions below the level of the lesion due to neuronal loss and axonal destruction [1-5]. World Health Organization survey data reveal that more than 180,000 patients experience SCI every year $[6,7]$, and the death rate of acute SCI ranges from $4.4 \%$ to $16.7 \%$ worldwide. As the aging population of modern society increases, the number of recorded patients with SCI resulting from falls has risen from $16 \%$ to $30.5 \%$ since 2012 [8-10]. Although several treatment strategies are available, such as surgical operation, pharmacological treatment and hyperbaric oxygenation therapy, no effective therapy is currently available for SCI [5]. Surgical decompression and fixation treatment can restore spine anatomical integrity and stability but has no apparent effect on neuron recovery [11]. Additionally, because of the blood-brain barrier (BBB), the clinical efficiency of therapeutic drugs is also very limited $[5,10,12,13]$. Therefore, further research on the pathological mechanism and effective treatment measures of SCI needs to be explored.

Tissue damage in SCI results from primary and secondary mechanisms [14]. The primary damage results from immediate primary mechanical injury of axons and neurons [14]. The secondary damage mechanisms include serious neuroinflammation, glutamate excitotoxicity, ischemia, edema, $\mathrm{Ca}^{2+}$ overload, compromised energy metabolism and increased reactive oxygen species (ROS) levels [15-18]. Due to increased permeability of the blood-spinal cord barrier, the infiltration of peripheral macrophages to the injury site is increased [12]. Injury triggering inflammation releases ROS, which could exacerbate SCI damage [19]. ROS, including superoxide anions, hydrogen peroxide, peroxynitrite, and hydroxyl radicals, can damage cells and tissues by oxidizing DNA, lipids and proteins, leading to cell dysfunction and cell death and contributing to neurodegeneration [19-21]. Recently, ROS have been described as playing important physiological roles in cellular signaling, such as in the process of cell proliferation, differentiation and metabolism, cancer activity [19, 22-24]. In addition, ROS may also trigger neutrophil-mediated inflammation, which is considered to contribute to secondary damage in SCI $[17,25]$. Arnau Hervera performed RNA-seq analysis, and the results showed that ROS could drive the inflammatory and immune response [19]. Therefore, we speculate that there is a cycle between ROS and neuroinflammation after SCI and that this cycle may extend the inflammatory period and inflammatory regions. Disruption of the cycle may be a potential effective treatment by reducing secondary damage. NF-kB and MAPK are the best characterized oxidation-reduction-sensitive 
signaling pathways, and the increase in ROS production could result in activation of the MAPK and NF-kB pathways $[22,26,27]$. P65 nuclear translocation can be attenuated by inhibiting the activation of the MAPK signaling pathway [28]. Hence, we hypothesized that the ROSMAPK-NFkB P65 signaling pathway may be an important signaling pathway regulating inflammation.

Recently, stem cell-derived exosomes have gained increasing attention in treating SCI. Exosomes are small particles secreted by living cells and formed from various proteins, including signal proteins, cytoskeletal proteins, and growth factors [29-31]. Exosomes can exercise biological roles through membrane signaling molecular recognition on the membrane surface and membrane fusion (including miRNA and mRNA) for intracellular regulation and extracellular release of active components, thus playing a neuroprotective role, regulating immunity and affecting cell behavior [32-35]. Compared with stem cells, stem cell-derived exosomes not only have most of the biological properties of stem cells but also have the advantage of a small volume and do not easily block microvessels. Exosomes have no growth proliferation capacity and low tumor risk and can penetrate the blood-spinal cord barrier with high membrane transport efficiency. Hence, exosomes have more potential and advantages in the treatment of SCI [10]. Many studies have demonstrated that stem cellderived exosomes can reduce ROS levels in injured tissue and reduce M1 macrophage polarization in an SCI model [10, 36, 37]. Currently, commonly used exosomes are mainly derived from bone marrow-derived mesenchymal stem cells (BMSCs), umbilical cord mesenchymal stem cells and adipose stem cells. A previous study showed that exosomes derived from dental pulp stem cells (DPSCs) had stronger immunomodulatory effects than exosomes derived from BMSCs $[38,39]$. DPSCs are generally extracted from discarded teeth without noninvasiveness, raising no ethical concerns [39]. Similar to the spinal cord, DPSCs also originate from the neural crest [39]. Hence, DPSC-derived exosomes may be an excellent candidate for treating SCI. However, there have been no studies of dental pulp stem cell (DPSC)-derived exosomes in the treatment of SCI. DPSCs can differentiate into a variety of cells in vitro and in vivo, such as neurons and glial cells [40]. It was demonstrated that transplantation of human dental pulp stem cells improves motor nerve function in rat SCI models [40]. DPSCs can also produce neurotrophins to support neural cell survival and promote the homing of endogenous neural stem cells to damaged sites after transplantation [41]. DPSCs have low immunogenicity and strong immunoregulatory ability [41]. However, the ability of DPSC-Exos to promote motor nerve function recovery in SCI models is unclear.
Many studies suggest that M1 macrophages can secrete inflammatory cytokines, such as IL- $1 \beta$ and TNF- $\alpha$, which further damage the cells [42-44]. Hence, we hypothesized that DPSC-derived exosomes can inhibit M1 macrophage polarization through the ROS-MAPK-NFkB P65 signaling pathway. The purpose of the present study was to investigate the neuroprotective mechanism of DPSCExos in treating SCI and to further explore whether DPSC-Exos could inhibit M1 macrophage polarization through the ROS-MAPK-NFKB P65 signaling pathway.

\section{Methods and materials Preparation of DPSCs}

Impacted human wisdom teeth were collected at the Dental Clinic of Beijing Stomatological Hospital under approved guidelines (BSH [2015] D-15). The patients' ages ranged from 19 to 29 years old. All patients provided written informed consent to participate. After cleaning tooth surfaces, the pulp chambers were exposed by cutting around the cementoenamel junction using a sterilized dental fissure burst.

DPSCs were isolated as described in previous work [39, 45]. Dental pulp was collected from the crown and root. After being cut into 1-mm pieces, the pulp was transferred into collagenase and dispase (Sigma-Aldrich, St. Louis, MO) and digested for $40 \mathrm{~min}$ at $37{ }^{\circ} \mathrm{C}$ in humid air with $5 \% \mathrm{CO}_{2}$. After washing with PBS, the pulp pieces were transferred into a cell culture flask to culture with alpha-modified Eagle's medium (alpha-MEM; Gibco; Thermo Fisher Scientific, Grand Island, NY) containing $15 \%$ fetal bovine serum (FBS; Thermo Fisher Scientific) at $37{ }^{\circ} \mathrm{C}$ in humid air with $5 \% \mathrm{CO}_{2}$. After 14 days of culture, the cells were harvested, and the surface molecule expression profiles and multilineage differentiation of MSCs were determined. (data shown in Additional file 1: Fig. S1).

\section{DPSCs-Exo isolation and characterization}

A total of $5 \times 10^{6}$ passage 4 DPSCs were seeded in a T-150 flask and cultured until $80 \%$ confluence. After washing the cells twice with PBS, $\alpha$-MEM without FBS was added to the flask, and the cells were cultured for $48 \mathrm{~h}$. Supernatants were collected. Exosomes were isolated from the supernatants of passage 4 DPSCs by differential centrifugation $(300 \times g$ for $10 \mathrm{~min}$; $2000 \times g$ for $10 \mathrm{~min} ; 10,000 \times g$ for $30 \mathrm{~min}, 100,000 \times g$ for $70 \mathrm{~min}$ ) and washing of the exosomes with PBS $(100,000 \times g$ for $70 \mathrm{~min})$. All centrifugations were performed at $4{ }^{\circ} \mathrm{C}$. Subsequently, the exosomes were resuspended in PBS and stored at $-80^{\circ} \mathrm{C}$.

Exosome morphology was observed with transmission electron microscopy. Ten microliters of the exosome suspension was loaded onto formvar/carbon-coated grids 
at $25{ }^{\circ} \mathrm{C}$ for $10 \mathrm{~min}$. Then, excess fluid was removed, exosomes were negatively stained with $3 \%$ aqueous phosphotungstic acid for $5 \mathrm{~min}$, and the exosome-containing grids were observed using a transmission electron microscope (HT7700, HITACHI, Tokyo, Japan) operating at $80 \mathrm{kV}$.The expression of exosome markers was also detected by western blot. Analysis of size distribution was performed using a Nanoparticle Tracker Analyzer (NTA, ZetaView, Particle Metrix Inc., Germany).

\section{RAW264.7 cell culture and experimental design}

RAW264.7 cell lines were used in this study. A total of $1 \times 10^{5}$ cells were seeded in the wells of 6-well plates and cultured in basic DMEM containing 10\% FBS (SigmaAldrich, St. Louis, MO). The cells cultured in the above medium were defined as $\mathrm{M} 0$ macrophages.

$\mathrm{H}_{2} \mathrm{O}_{2}$ was used to treat RAW264.7 cells to investigate whether ROS signaling supports macrophage polarization and to determine the role of ROS concentration in the macrophage polarization process. RAW264.7 cells were randomly divided into seven groups: the control, $50 \mu \mathrm{M}, 100 \mu \mathrm{M}, 150 \mu \mathrm{M}, 200 \mu \mathrm{M}, 250 \mu \mathrm{M}$ and $500 \mu \mathrm{M}$ groups. The concentration of $\mathrm{H}_{2} \mathrm{O}_{2}$ we used in the following study was $500 \mu \mathrm{M}$.

Lipopolysaccharide (LPS, $100 \mathrm{ng} / \mathrm{mL}$, Sigma-Aldrich) was used to treat RAW264.7 cells. RAW264.7 cells were randomly divided into three groups: the control, LPS and LPS + Exos groups. The LPS + Exos group was treated with both LPS and DPSC-Exos. DPSC-Exos were used to grow RAW264.7 cells at a concentration of $10 \mu \mathrm{g} / \mathrm{ml}$.

A $10 \mu \mathrm{mol} / \mathrm{ml}$ nonselective inhibitor of the ROS-producing flavoenzyme diphenyleneiodonium (DPI) (Selleckchem, Houston, TX, USA) was used to inhibit ROS production. RAW264.7 cells were randomly divided into four groups: the control, LPS, LPS + DPI, and LPS + DPI $+\mathrm{H}_{2} \mathrm{O}_{2}$ groups. Furthermore, RAW264.7 cells were also randomly divided into three groups: the control, $\mathrm{H}_{2} \mathrm{O}_{2}$ and $\mathrm{H}_{2} \mathrm{O}_{2}+$ DPI groups.

To dissect the role of P65, the antagonist BAY 11-7082 (Beyotime Shanghai, China) $(10 \mu \mathrm{mol} / \mathrm{ml})$ was used to suppress the P65 signaling pathway. RAW264.7 cells were randomly divided into three groups: the control, $\mathrm{H}_{2} \mathrm{O}_{2}$ and $\mathrm{H}_{2} \mathrm{O}_{2}+\mathrm{BAY}$ 11-7082 groups. RAW264.7 cells were also randomly divided into three groups: the control, LPS and LPS + BAY 11-7082 groups.

To dissect the role of MAPK, PD98059 (AbMole Bioscience Inc, Houston, TX, USA) $(10 \mu \mathrm{mol} / \mathrm{ml})$ was used to suppress the ERK1/2 signaling pathway. RAW264.7 cells were randomly divided into three groups: the control, $\mathrm{H}_{2} \mathrm{O}_{2}$ and $\mathrm{H}_{2} \mathrm{O}_{2}+\mathrm{PD} 98059$ groups. Furthermore, RAW264.7 cells were also randomly divided into three groups: the control, LPS and LPS + PD98059 groups.

\section{RNA extraction and quantitative RT-PCR analysis}

After 2, 4, and $6 \mathrm{~h}$ of culture with LPS or $\mathrm{H}_{2} \mathrm{O}_{2}$ in vitro, total RNA was extracted from RAW264.7 cells using TRIzol reagent (Invitrogen, USA) according to the manufacturer's protocol. RNA concentration and sample purity were measured using an ultraviolet spectrophotometer (UVS-99, ACTGene, USA). The purity of extracted RNA was approximately 2.0. Complementary DNA (cDNA) was synthesized from total RNA using StarScript II First-strand cDNA Synthesis Mix with gDNA Remover (GenStar, China). The expression level of the gene was detected by qRT-PCR using RealStar Green Fast Mixture with ROX II (GenStar, China).

The ACTIN level was used to normalize the gene-specific expression levels. PCRs in $20 \mu \mathrm{l}$ were carried out in triplicate. The PCR conditions were as follows: initial denaturation at $95{ }^{\circ} \mathrm{C}$ for 2 min followed by 40 cycles, each consisting of $15 \mathrm{~s}$ at $95{ }^{\circ} \mathrm{C}, 30 \mathrm{~s}$ at $60{ }^{\circ} \mathrm{C}, 30 \mathrm{~s}$ at $72{ }^{\circ} \mathrm{C}$ and then 1 cycle for the melting curve. The primer sequences were as follows: $\mathrm{m}$-Actin, forward, $5^{\prime}$-CCT CACTGTCCACCTTCC- $3^{\prime}$ and reverse $5^{\prime}$ - GGGTGT AAAACGCAGCTC-3'; m-iNOS, forward 5'-GCCCAG GAGGAGAGAGAT- $3^{\prime}$ and reverse $5^{\prime}$-GCAAAGAGG ACTGTGGCT-3'.

\section{Flow cytometry}

After 2, 4, 6, and $24 \mathrm{~h}$ of LPS or LPS + Exos pretreatment and removal of the supernatant, the cells were washed twice with PBS. Then, after incubation with H2DCFDA (C6827, Thermo Fisher Scientific, Grand Island, NY) for $60 \mathrm{~min}$ at $37^{\circ} \mathrm{C}$ in the dark, the cells were collected and washed twice with PBS and resuspended in $500 \mu \mathrm{L}$ of PBS. ROS was detected by flow cytometry (FACS Calibur, BD, USA).

After $24 \mathrm{~h}$ of culture with LPS, LPS + Exos, $\mathrm{H}_{2} \mathrm{O}_{2}$, LPS + DPI, $\mathrm{H}_{2} \mathrm{O}_{2}+$ DPI, LPS + P65 inhibitor, $\mathrm{H}_{2} \mathrm{O}_{2}+\mathrm{P} 65$ inhibitor, LPS + PD98059 or $\mathrm{H}_{2} \mathrm{O}_{2}+\mathrm{PD} 98059$, the expression levels of M1 macrophage surface markers were detected by flow cytometry. At $24 \mathrm{~h}$ post-treatment, cells were harvested and washed twice with PBS and then incubated with anti-CD86-PE (Thermo Fisher 12-086282 ) according to the manufacturer's protocol. After incubation with anti-CD86-PE for $30 \mathrm{~min}$ at $4{ }^{\circ} \mathrm{C}$ in the dark, the cells were washed twice with PBS and resuspended in $500 \mu \mathrm{L}$ of PBS. Cell surface expression was detected using flow cytometry.

After $24 \mathrm{~h}$ of culture with LPS, LPS + Exos, $\mathrm{H}_{2} \mathrm{O}_{2}, \quad$ LPS + DPI, $\mathrm{H}_{2} \mathrm{O}_{2}+$ DPI, LPS + PD98059 or $\mathrm{H}_{2} \mathrm{O}_{2}+\mathrm{PD} 98059$, $\mathrm{P} 65$ was detected by flow cytometry. At $24 \mathrm{~h}$ post-treatment, cells were harvested and washed twice with PBS and then fixed for $15 \mathrm{~min}$ at room temperature with $4 \%$ formaldehyde. Cells were washed twice with $1 \times$ PBS. Cells were permeabilized by adding 
ice-cold $100 \%$ methanol slowly to prechilled cells while gently vortexing to a final concentration of $90 \%$ methanol, followed by permeabilization for a minimum of 10 min on ice. The cells were washed by centrifugation in excess $1 \times$ PBS to remove the methanol. The cells were incubated with anti-p65-Alexa Fluor 488 (CST 494455) for $1 \mathrm{~h}$ at room temperature in the dark. Cells were washed twice by centrifugation in antibody dilution buffer and resuspended in $500 \mu \mathrm{L}$ of PBS. P65 was then detected using flow cytometry.

At 3 days and 5 days after SCI, 3-mm spinal cord segments were resected from mice centered on the injury epicenter. After washing with PBS, the endorachis and blood vessels were removed from the spinal cord tissues and placed under a microscope. After being cut into small pieces, the spinal cord tissues were transferred into culture medium with $2 \%$ papain for $25 \mathrm{~min}$ at $37^{\circ} \mathrm{C}$ and vertexed once every five minutes. After centrifugation at $200 \mathrm{rpm}$ for two min, the supernatant was collected. After centrifugation at $1000 \mathrm{rpm}$ for five min,the supernatant was discarded. Cells were washed twice with $1 \times$ PBS. Then, the cells were incubated with H2DCFDA (C6827, Thermo Fisher Scientific, Grand Island, NY) for $60 \mathrm{~min}$ at $37^{\circ} \mathrm{C}$ in the dark. The cells were collected and washed twice with PBS and resuspended in $500 \mu \mathrm{L}$ of PBS. ROS was detected by flow cytometry (FACS Calibur, BD, USA).

\section{Western blot}

Exosomes were lysed in RIPA buffer with protease inhibitors. Cells and spinal cord tissues were lysed in RIPA buffer with protease and phosphatase inhibitors (Beyotime Shanghai, China). The concentrations of proteins were measured using a Pierce ${ }^{\mathrm{TM}}$ BCA Protein Assay Kit (Rockford, IL, USA). Then, the preparations were mixed with $5 \times$ SDS loading buffer, denatured at $100{ }^{\circ} \mathrm{C}$ for $10 \mathrm{~min}$ and loaded onto a 10\% SDS-PAGE gel for electrophoresis. After electrophoresis and washing with TBS-T, proteins were transferred to $0.22-\mu \mathrm{m}$ polyvinylidene difluoride membranes (Bio-Rad, USA) and then blocked with $5 \%$ nonfat milk. The membranes were incubated with the following primary antibodies overnight at $4{ }^{\circ} \mathrm{C}$ : $\mathrm{CD} 9$ antibody (diluted 1:1000, Abcam, catalog number: ab92726), CD63 antibody (diluted 1:1000, Abcam, catalog number: ab134045), tubulin (diluted 1:3000, Servicebio, catalog number: GB11017B), albumin (diluted 1:1000, Abcam, catalog number: ab151742), CD73 antibody (diluted 1:1000, Abcam, catalog number: ab133582), p42/44 antibody (diluted 1:1000, CST, catalog number: 9102), and p-p42/44 antibody (diluted 1:1000, CST, catalog number: 9101). The next day, the membranes were washed with TBST four times for 5 min each time, and then the membranes were incubated for $1 \mathrm{~h}$ with secondary antibody (1:6000) at room temperature. After washing the membranes with TBST more than four times, the blots were detected using electrochemiluminescence plus reagent (Invitrogen, USA). Protein band densities were assessed by CS Analyzer software (Version 3.00.1011, ATTO \& Rise Corporation).

\section{Mice}

Six- to eight-week-old female C57BL/6 mice were obtained from Charles River Laboratories (Beijing, China). All mice weighed 17.4-22 g at the time of surgery. All animals were maintained under constant temperature and humidity conditions and experienced a 12-h/12-h light/dark cycle. All animal experiments were performed under protocols approved by the Institutional Animal Care and Use Committee of the Beijing Institute of Radiation Medicine (IACUC-DWZX-2020-717).

\section{Animal model of spinal cord injury}

A contusive SCI model was established using a New York University Impactor, as previously described [46]. Briefly, mice were anesthetized with an intraperitoneal injection of pentobarbital $(50 \mathrm{mg} / \mathrm{kg}$ ). A laminectomy was performed at the T11-12 level. After laminectomy and exposing the dorsal surface of the cord, a 10-g rod was dropped from a height of $6.25 \mathrm{~mm}$, hitting the stabilized spine and damaging the cord. After cord injury was achieved, the incision was sutured layer by layer.

\section{Treatment of hDPSC-derived exosomes in SCl}

All SCI mice were randomly assigned to two groups, and each group included 12 mice. Thirty minutes after the surgery, $100 \mu \mathrm{l}$ of PBS or $200 \mu \mathrm{g} / 100 \mu \mathrm{l} \mathrm{hDPSC}$-derived exosomes were administered through the tail vein. Mice were placed in a controlled environment. Until reflex bladder emptying ability was restored, manual bladder emptying was performed twice each day.

\section{Spinal cord function evaluation}

At $1,3,5,7,14,21$ and 28 days post-SCI, the recovery of spinal cord function was evaluated through Basso Mouse Scale (BMS) scoring. The BMS score ranges from 0 to 9 points; 0 points represents full paralysis, and 9 points represents complete normality [47]. The mice were kept on a flat area and allowed free movement for $4 \mathrm{~min}$. Hindlimb movement function was assessed by two independent observers. For each mouse, the mean BMS score was adopted as the individual BMS score.

\section{Immunofluorescent staining Cell immunofluorescent staining}

The cultured cells were washed with PBS three times. After fixation with $4 \%$ polyformaldehyde for $15 \mathrm{~min}$, the 
cells were washed with PBS three times. Next, the cells were permeabilized for 20 min with $0.5 \%$ Triton- $\times 100$ and then washed with PBS three times. The cells were blocked with 5\% BSA for 30 min and then incubated with anti-p65 antibody in a humidified chamber overnight at $4{ }^{\circ} \mathrm{C}$. Cells were washed with PBS three times and then incubated with secondary antibody for $60 \mathrm{~min}$ at room temperature in the dark. After washing three times, the cells were incubated with DAPI solution in the dark for $5 \mathrm{~min}$ to stain the cell nuclei. Samples were photographed with an OLYMPUS CKX53 (Tokyo Japan).

\section{Tissue immunofluorescent staining}

A $10-\mathrm{mm}$ spinal cord segment was resected from mice at 3,5 and 28 days after surgery. The spinal cord tissues were soaked in $4 \%$ paraformaldehyde for $24 \mathrm{~h}$ and then transferred into $30 \%$ sucrose solution until the tissue sank. Frozen spinal cord tissues were cut into $10-\mu \mathrm{m}$ slices (Leica, Germany). Slices were incubated with antiCD86 antibody, anti-P65 antibody, anti-NF200 antibody, and anti-NEUN antibody in a humidified chamber overnight at $4{ }^{\circ} \mathrm{C}$, incubated with the secondary antibody marked with HRP, and then incubated with CY3-TSA or FITC-TSA solution. An inverted fluorescence microscope (Leica DM6000, Wetzlar, Germany) was applied for photographing samples and further analysis.

\section{Statistical analysis}

Data analysis was performed using GraphPad Prism 7.0 (San Diego, CA, USA). The data are presented as the mean \pm SD. Two-way ANOVA was adopted to compare BMS scores between groups over time. The remaining data were analyzed using Student's t test or one-way ANOVA with Tukey's multiple comparison test. A P value less than 0.05 was considered to be significant in all analyses.

\section{Results \\ ROS have a concentration-dependent effect on M1 macrophage polarization, and LPS can promote M1 macrophage polarization by inducing ROS production}

In vitro, we cultured RAW264.7 cells with different concentrations of $\mathrm{H}_{2} \mathrm{O}_{2}$ (ranging from $50 \mu \mathrm{mol} / \mathrm{L}$ to $500 \mu \mathrm{mol} / \mathrm{L}$ ) for $24 \mathrm{~h}$. The flow cytometry analysis results revealed that there was a concentration-dependent promoting effect on M1 macrophage polarization. The M1 polarization rate was increased with an increased $\mathrm{H}_{2} \mathrm{O}_{2}$ concentration in the culture medium $(0 \mu \mathrm{mol} / \mathrm{L}: 2.647 \pm 0.358$, $50 \mu \mathrm{mol} / \mathrm{L}: 6.003 \pm 0.5424, \quad 100 \mu \mathrm{mol} / \mathrm{L}: 8.05 \pm 0.2787$, $150 \mu \mathrm{mol} / \mathrm{L}: 8.263 \pm 0.1656, \quad 200 \mu \mathrm{mol} / \mathrm{L}: 9.56 \pm 0.3236$, $250 \mu \mathrm{mol} / \mathrm{L}: 11.4 \pm 0.755, \quad 500 \quad \mu \mathrm{mol} / \mathrm{L}: 17.97 \pm 1.617)$ (Fig. 1A, B). We also detected the effect of a higher $\mathrm{H}_{2} \mathrm{O}_{2}$ concentration $(1 \mathrm{mmol} / \mathrm{L})$ on $\mathrm{M} 1$ polarization and found that it reached a toxic level and mainly induced cell death (data shown in Additional file 2: Fig. S2). Hence, ROS can induce M1 macrophage polarization within a certain range of concentrations and have a concentration-dependent effect.

Then, we cultured RAW264.7 cells with LPS for 2, 4, 6 and $24 \mathrm{~h}$. ROS levels were detected using FACS, and the results showed that ROS levels were significantly increased as early as $2 \mathrm{~h}$ after LPS treatment $(0 \mathrm{~h}: 50.5 \pm 2.052$, 2 h:140.7 $\pm 26.31,4$ h: $141.3 \pm 19.43,6$ h: $156.3 \pm 13.05$, 24 h: $247.7 \pm 11.5$ ) (Fig. 1C, D). Moreover, total RNA was extracted from RAW264.7 cells, and quantitative RT-PCR analysis was performed. We found that both LPS ( $0 \mathrm{~h}$ vs $6 \mathrm{~h}: 1 \pm 0.086$ vs $1.17 \pm 0.061)$ and $\mathrm{H}_{2} \mathrm{O}_{2}(0 \mathrm{~h}$ vs $6 \mathrm{~h}: 1 \pm 0.126$ vs $1.47 \pm 0.122)$ markedly upregulated the expression of iNOS, a marker of M1 macrophages, at $6 \mathrm{~h}$ after LPS and $\mathrm{H}_{2} \mathrm{O}_{2}$ treatment (Fig. 1E, F). These results suggest that ROS may mediate LPS-induced M1 macrophage polarization.

\section{ROS activate M1 macrophage polarization}

\section{through the MAPK-NFKB P65 signaling pathway}

To verify that ROS may mediate LPS-induced M1 macrophage polarization, we inhibited the production of ROS induced by LPS. Diphenyleneiodonium (DPI) is a nonselective inhibitor of ROS-producing flavoenzymes. The LPS + DPI group had a markedly lower M1 polarization rate than the LPS group (LPS+DPI vs LPS: $21.03 \pm 0.945$ vs $32.6 \pm 2.358$ ). Furthermore, the $\mathrm{LPS}+\mathrm{DPI}+\mathrm{H}_{2} \mathrm{O}_{2}$ group had a significantly increased M1 polarization rate compared with the LPS +DPI group (LPS $+\mathrm{DPI}+\mathrm{H}_{2} \mathrm{O}_{2}$ vs LPS + DPI: $35.33 \pm 2.228$ vs $21.03 \pm 0.945$ ) (Fig. $2 \mathrm{~A}, \mathrm{~B}$ ). Western blot results showed that LPS upregulated the P-ERK/ERK level in RAW264.7 cells and that DPI downregulated the LPS-induced increase in the P-ERK/ERK level (LPS+DPI vs LPS: $0.671 \pm 0.081$ vs $0.833 \pm 0.031$ ). The LPS $+\mathrm{DPI}+\mathrm{H}_{2} \mathrm{O}_{2}$ group had a higher P-ERK/ERK level than the $\mathrm{LPS}+\mathrm{DPI}$ group ( $\mathrm{LPS}+\mathrm{DPI}+\mathrm{H}_{2} \mathrm{O}_{2}$ vs

(See figure on next page.)

Fig. 1 ROS has a concentration-dependent effect on macrophages M1 polarization, and LPS can promote macrophages M1 polarization by inducing ROS production. A and B Raw264.7 cells cultured with different concentration of $\mathrm{H}_{2} \mathrm{O}_{2}$ (ranging from $50 \mu \mathrm{mol} / \mathrm{L}$ to $500 \mu \mathrm{mol} / \mathrm{L}$ ) for $24 \mathrm{~h}$. M1 polarization rate was increased with an increased $\mathrm{H}_{2} \mathrm{O}_{2}$ concentration in the culture medium. $\mathbf{C}$ and $\mathbf{D}$ Raw264.7 cells cultured with LPS for 2 , 4, 6 and 24 h. ROS level was detected by using FACS with a flow cytometry. $\mathbf{E}$ and $\mathbf{F}$ Raw264.7 cells cultured with LPS or $\mathrm{H}_{2} \mathrm{O}_{2}$ for 2, 4 and 6 h.The mRNA (iNOS) relative expression level of M1 phase is detected. Both LPS and $\mathrm{H}_{2} \mathrm{O}_{2}$ markedly upregulated the expression of iNOS at $6 \mathrm{~h}$ after LPS and $\mathrm{H}_{2} \mathrm{O}_{2}$ treatment. ${ }^{*} \mathrm{p}<0.05,{ }^{* * *} \mathrm{p}<0.01$ 
A
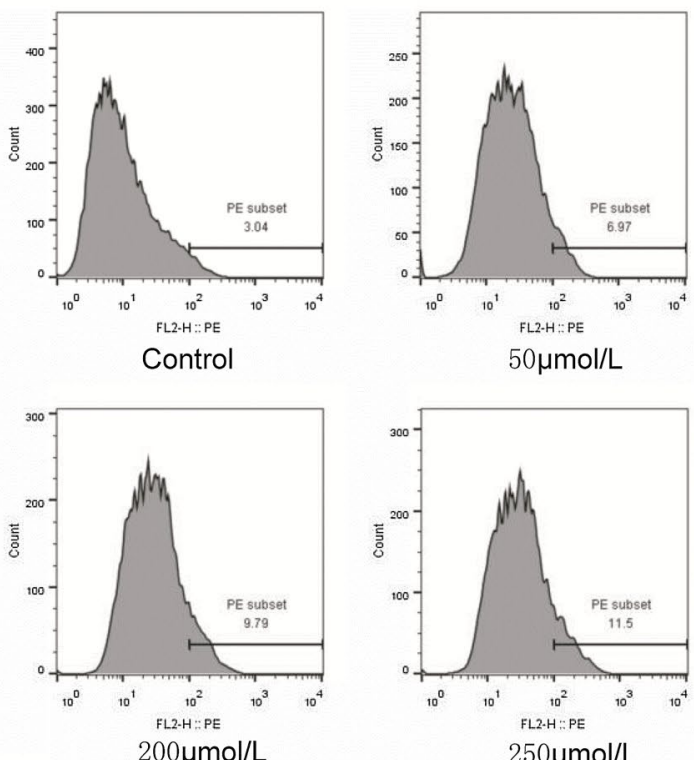

B

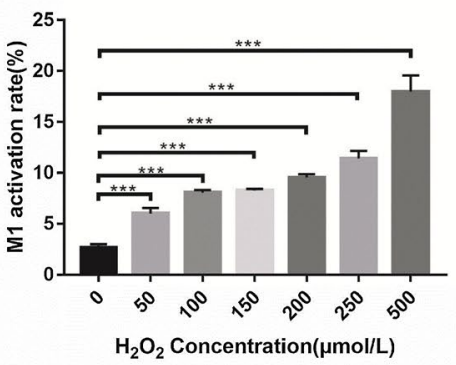

C

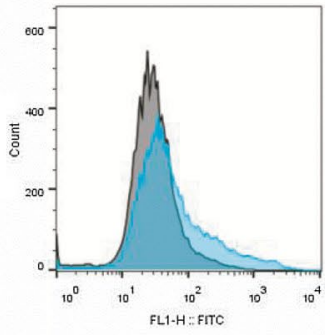

$2 \mathrm{~h}$
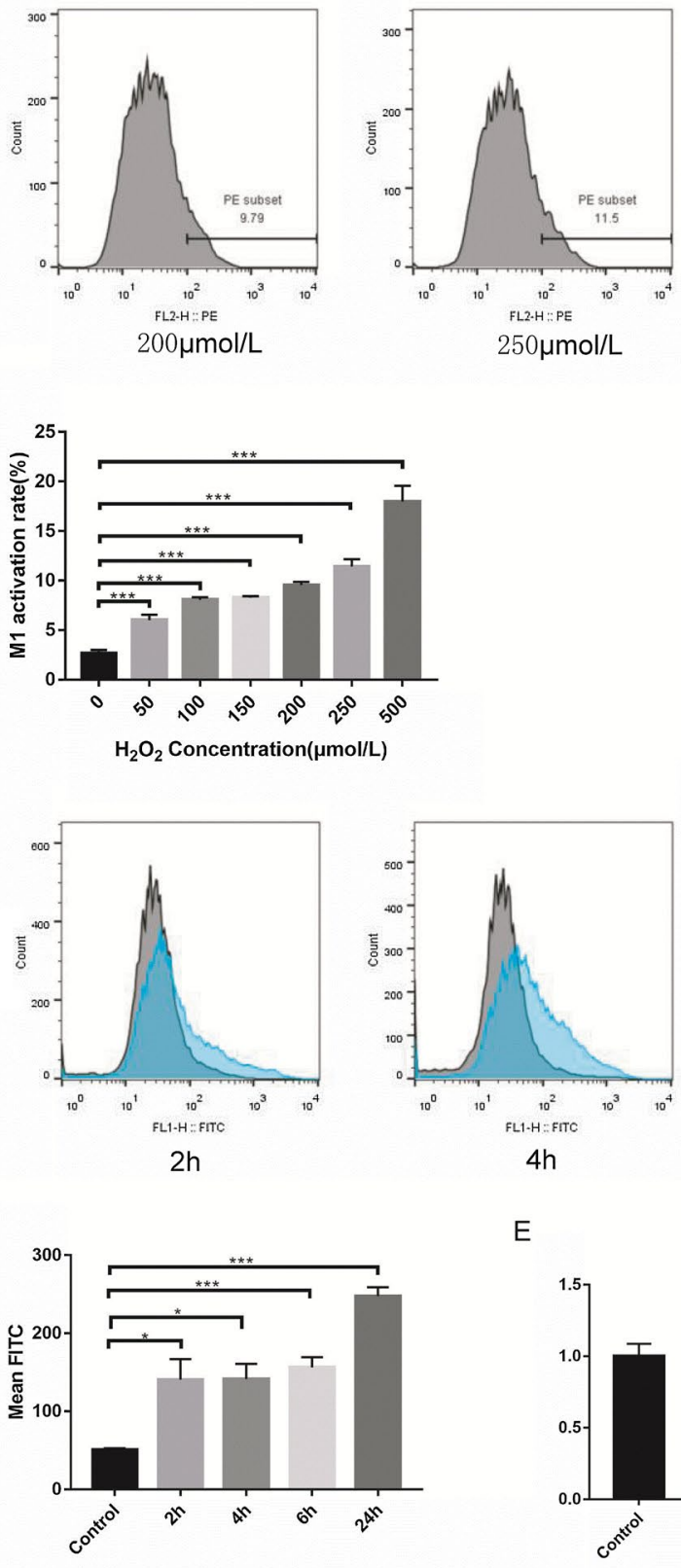

E
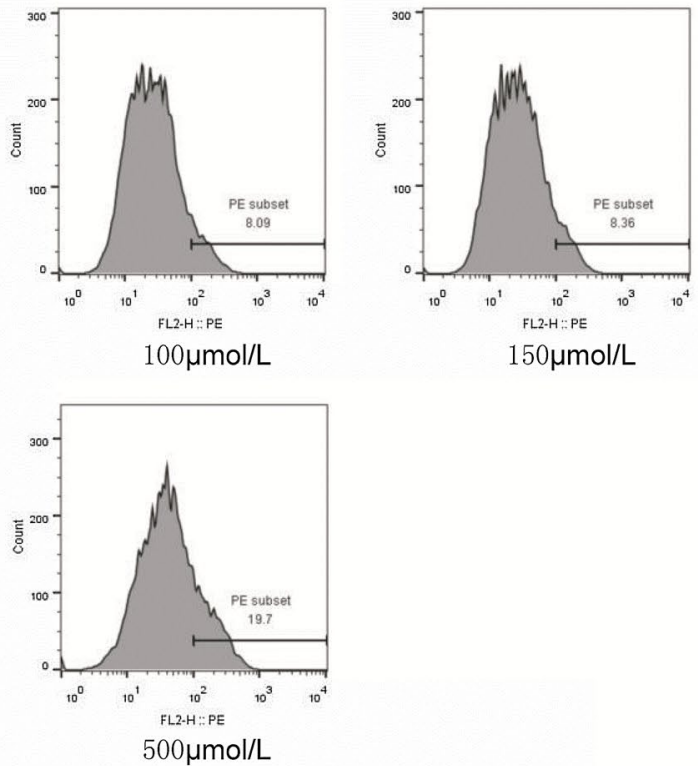

- LPS

- Control

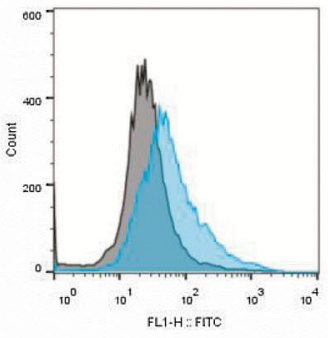

$6 \mathrm{~h}$

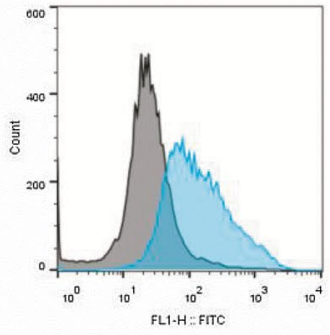

$24 \mathrm{~h}$

INOS

F
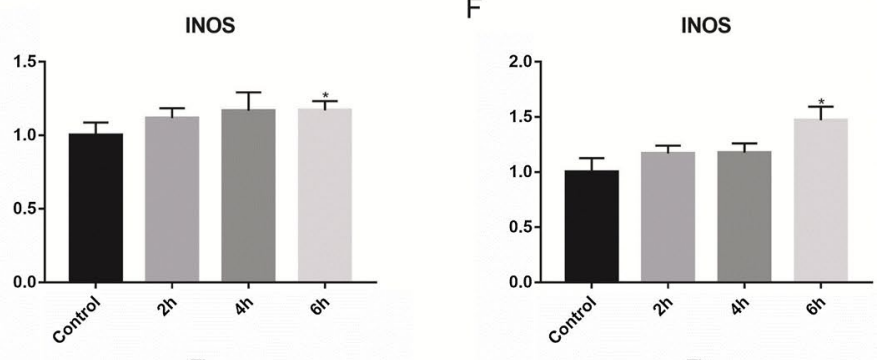

Fig. 1 (See legend on previous page.) 
LPS + DPI:0.804 \pm 0.033 vs $0.671 \pm 0.081$ ) (Fig. 2C, D). Flourescence microscopy and flow cytometry were used to detect the expression of P65, and the results showed that LPS could increase P65 expression (Control vs LPS: $17.87 \pm 1.419$ vs $63.73 \pm 6.152$ ). DPI had a marked inhibitory effect on the increase in P65 fluorescence (LPS vs LPS + DPI: $63.73 \pm 6.152$ vs $39.87 \pm 3.371)$, and $\mathrm{H}_{2} \mathrm{O}_{2}$ counteracted the inhibitory effect of DPI (LPS + DPI $+\mathrm{H}_{2} \mathrm{O}_{2}$ vs LPS + DPI: $57.7 \pm 2.858$ vs $39.87 \pm 3.371)$ (Fig. $2 \mathrm{E}-\mathrm{G}$ ). Furthermore, we demonstrated that $\mathrm{H}_{2} \mathrm{O}_{2}$ could promote $\mathrm{M} 1$ macrophage polarization (Control vs $\mathrm{H}_{2} \mathrm{O}_{2}: 3.227 \pm 0.158$ vs $19.2 \pm 0.361$ ), but DPI had no effect on M1 macrophage polarization induced by $\mathrm{H}_{2} \mathrm{O}_{2}\left(\mathrm{H} 2 \mathrm{O} 2+\right.$ DPI vs $\mathrm{H}_{2} \mathrm{O}_{2}$ : $18.67 \pm 0.588$ vs $19.2 \pm 0.361$ ) (Fig. 3A, B). Western blot results also showed that $\mathrm{H}_{2} \mathrm{O}_{2}$ could increase the P-ERK/ ERK level (Control vs H2O2: $0.397 \pm 0.018$ vs $0.718 \pm 0.134$ ) and that DPI had no influence on the phosphorylation of ERK in cells cultured with $\mathrm{H}_{2} \mathrm{O}_{2}(\mathrm{H} 2 \mathrm{O} 2+$ DPI vs $\mathrm{H} 2 \mathrm{O} 2$ : $0.767 \pm 0.171$ vs $0.718 \pm 0.134$ ) (Fig. $3 \mathrm{C}, \mathrm{D})$. P65 expression was also increased after $\mathrm{H}_{2} \mathrm{O}_{2}$ treatment for $24 \mathrm{~h}$ (Control vs $\mathrm{H} 2 \mathrm{O} 2: 17.87 \pm 1.419$ vs $39 \pm 1.473$ ), and DPI could not suppress the P65 fluorescence increase caused by $\mathrm{H}_{2} \mathrm{O}_{2}(\mathrm{H} 2 \mathrm{O} 2+$ DPI vs $\mathrm{H} 2 \mathrm{O} 2: 39.83 \pm 5.16$ vs $39 \pm 1.473)$ (Fig. 3E-G).

P65 was an important factor in $\mathrm{M} 1$ macrophage polarization caused by both LPS and $\mathrm{H}_{2} \mathrm{O}_{2}$. To further support our findings, the antagonist BAY 11-7082 (a P65 inhibitor) was introduced. The flow cytometry analysis results revealed that macrophage M1 polarization caused by both LPS and $\mathrm{H}_{2} \mathrm{O}_{2}$ could be suppressed by the P65 inhibitor (LPS + BAY11-7082 vs LPS: $23.6 \pm 1.453$ vs $33.5 \pm 1.67 ; \mathrm{H}_{2} \mathrm{O}_{2}+\mathrm{BAY} 11-$ 7082 vs $\mathrm{H}_{2} \mathrm{O}_{2}: 6.89 \pm 1.195$ vs $20 \pm 0.94$ ) (Fig. $3 \mathrm{H}-\mathrm{K}$ ). The results also revealed that PD98059, an inhibitor of MEK, could also inhibit P65 expression (LPS + PD98059 vs LPS: $24.77 \pm 1.222$ vs $33.5 \pm 1.67$; $\mathrm{H}_{2} \mathrm{O}_{2}+\mathrm{PD} 98059$ vs $\mathrm{H}_{2} \mathrm{O}_{2}: 7.903 \pm 0.773$ vs $20 \pm 0.94$ ) and that M1 macrophage polarization was increased by LPS or $\mathrm{H}_{2} \mathrm{O}_{2}$ (LPS + PD98059 vs LPS: $35 \pm 3.032$ vs $63.73 \pm 6.152 ; \mathrm{H}_{2} \mathrm{O}_{2}+\mathrm{PD} 98059$ vs $\mathrm{H}_{2} \mathrm{O}_{2}: 31.93 \pm 1.626$ vs $39 \pm 1.473$ ) (Fig. $3 \mathrm{H}-\mathrm{N}$ ).

\section{Isolation and identification of DPSC-derived exosomes}

Exosomes were isolated with differential centrifugation from passage 4 DPSC culture supernatant. The structure of exosomes was photographed with TEM (Fig. 4A), which showed numerous saucer-shaped vesicles. TRPS analysis showed a diameter of approximately $100 \mathrm{~nm}$ (Fig. 4A) and a concentration of $2.2 \mathrm{E}+11$ particles/ $\mathrm{ml}$. The expression of the exosome markers CD63 and CD9, tubulin, albumin and the MSC marker CD73 in the DPSC-Exo samples (Fig. 4A) and DPSC proteins (Fig. 4A) was verified by western blot. These results demonstrated that the isolated extracellular vesicles were hDPSCderived exosomes. Furthermore, the protein concentration was $2.0 \mu \mathrm{g} / \mu \mathrm{l}$ in the exosomes quantified using the BCA protein assay kit.

\section{DPSC-derived exosomes could inhibit M1 macrophage polarization through the MAPK-NFKB P65 signaling pathway}

Additionally, we used exosomes to treat RAW264.7 cells to observe the protective effect on LPS-induced cell damage in vitro. The LPS + Exos group had a lower ROS level than the LPS group at $2 \mathrm{~h}$ (LPS vs LPS + EXO: $140.667 \pm 26.312$ vs $66.7 \pm 6.482), 4 \mathrm{~h}$ (LPS vs LPS + EXO: $141.333 \pm 19.425$ vs $63.267 \pm 11.188), 6 \mathrm{~h}$ (LPS vs LPS + EXO: $156.333 \pm 13.051$ vs $81.133 \pm 4.409)$ and $24 \mathrm{~h}$ (LPS vs LPS + EXO: $247.667 \pm 11.054$ vs $149.333 \pm 8.505$ ) after treatment (Fig. 4B, C). The flow cytometry analysis results showed that DPSC-derived exosomes could lower the LPS-induced increase in the M1 polarization rate of RAW264.7 cells (LPS vs LPS + EXO: $33.67 \pm 1.79$ vs $21.43 \pm 1.922$ ) (Fig. 4D, E). Western blot results revealed that the LPS + Exos group had a lower P-ERK/ERK level than the LPS group(LPS vs LPS +EXO: $0.877 \pm 0.064$ vs $0.709 \pm 0.051$ ) (Fig. 4F, G). DPSC-derived exosomes also inhibited the increase in P65 fluorescence induced by LPS (LPS vs LPS + EXO: $63.73 \pm 6.152$ vs $27.6 \pm 2.506$ ) (Fig. 4H-J). Hence, all the above mentioned results demonstrated that DPSC-derived exosomes could inhibit M1 macrophage polarization through the ROS-MAPK-NFKB P65 signaling pathway in vitro.

\footnotetext{
(See figure on next page.)

Fig. 2 DPI can suppress macrophages M1 polarization and MAPK-NFKB P65 signaling pathway. A and B Raw264.7 cells were treated with LPS, LPS + DPI or LPS + DPI + $\mathrm{H}_{2} \mathrm{O}_{2} \cdot \mathrm{M} 1$ macrophages surface expression (CD86) was detected using using flow cytometry. The LPS + DPI group had a markedly lower M1 polarization rate than the LPS group. Furthermore, the LPS $+\mathrm{DPI}+\mathrm{H}_{2} \mathrm{O}_{2}$ group had a significantly increased M1 polarization rate compared with the LPS + DPI group. C and D The ERK1/2 and p-ERK1/2 protein expression in Raw264.7 cells was either investigated. LPS upregulated the P-ERK/ERK level in RAW264.7 cells and that DPI downregulated the LPS-induced increase in the P-ERK ERK level. The LPS + DPI + H2O2 group had a higher P-ERK/ERK level than the LPS + DPI group. E-G P65 protein expression are determined by immunofluorescences and flow cytometry. LPS could increase P65 expression. DPI had a marked inhibitory effect on the increase in P65 fluorescence, and $\mathrm{H} 2 \mathrm{O} 2$ counteracted the inhibitory effect of DPI. $\mathrm{p} p 0.05$, ${ }^{* * *} \mathrm{p}<0.01$
} 
A

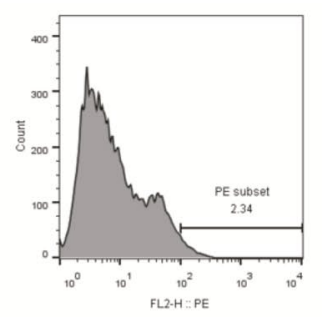

Control

B

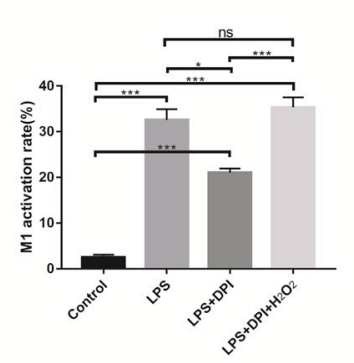

E

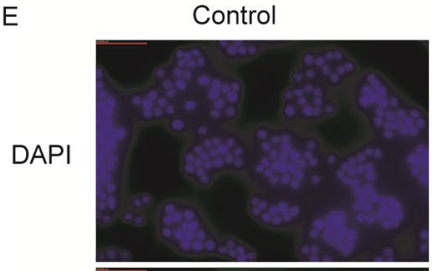

P65
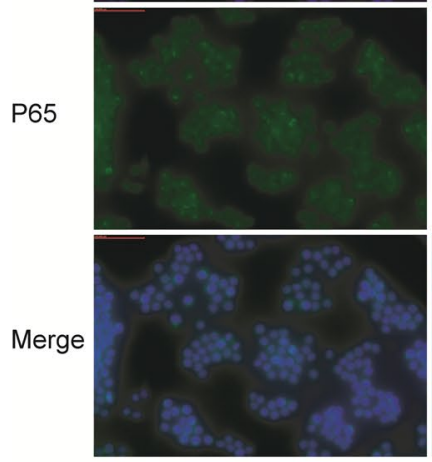

F

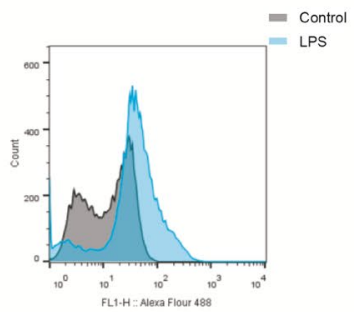

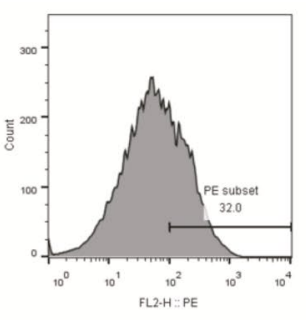

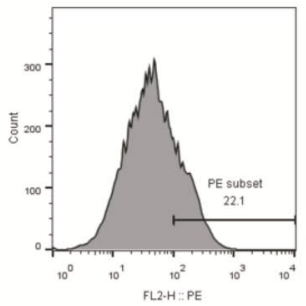

LPS+DPI

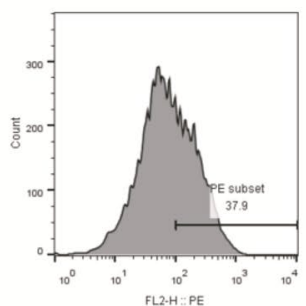

$\mathrm{LPS}+\mathrm{DPI}+\mathrm{H}_{2} \mathrm{O}_{2}$
C

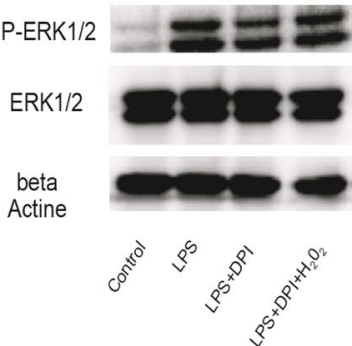

LPS
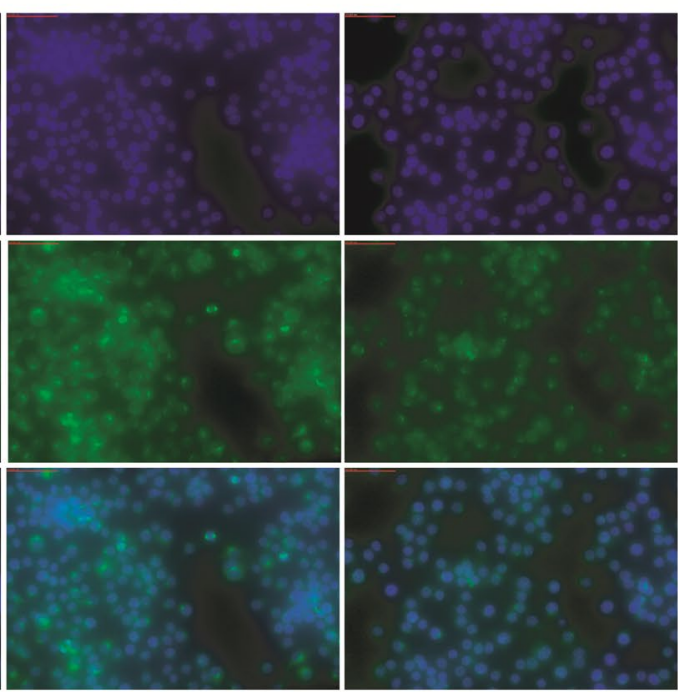

LPS+DPI

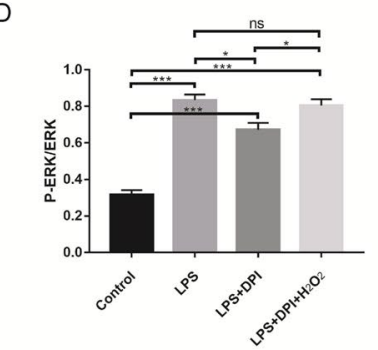

$\mathrm{LPS}+\mathrm{DPI}+\mathrm{H}_{2} \mathrm{O}_{2}$

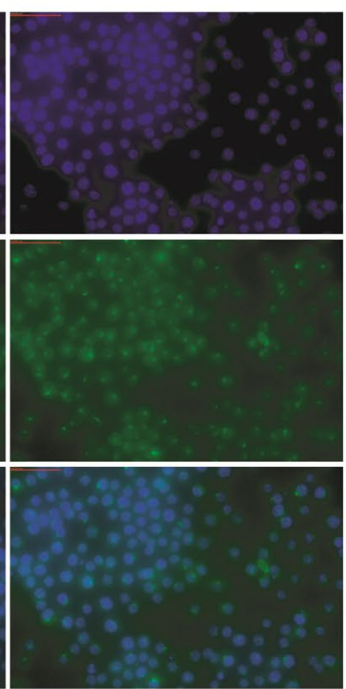

G
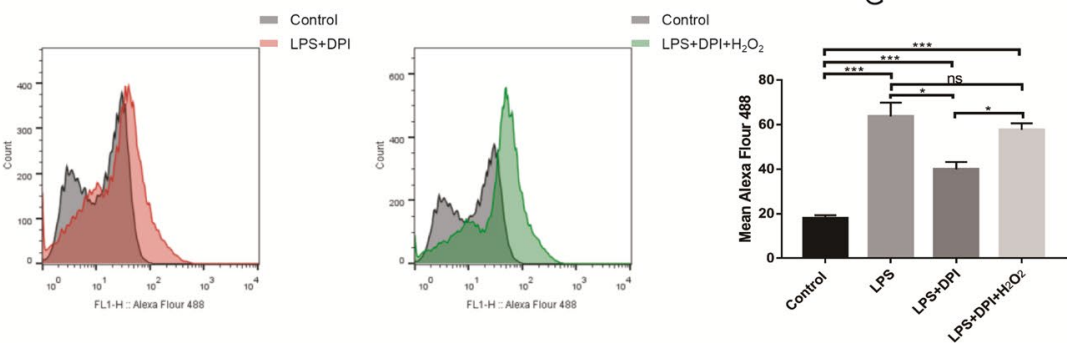

Fig. 2 (See legend on previous page.) 


\section{DPSC-derived exosomes can inhibit the ROS-MAPK-NFKB P65 signaling pathway in vivo}

At 3 and 5 days after spinal cord injury, flow cytometry analysis was performed. The results showed that there was a marked increase in ROS levels in the injured spinal cord at 3 days (Sham vs PBS vs EXO: $26.2 \pm 1.572$ vs $45.13 \pm 1.25$ vs $36.7 \pm 1.251$ ) (Fig. $5 \mathrm{~A}, \mathrm{~B}$ ) and 5 days(Sham vs PBS vs EXO:: $26.2 \pm 1.572$ vs $31.5 \pm 0.624$ vs $29.07 \pm 1.115$ ) (Fig. 5 C, D) after SCI. Western blot results revealed that there was also a higher P-ERK/ERK level in the SCI group than in the sham group at 3 days (Sham vs PBS vs EXO: $0.506 \pm 0.031$ vs $0.903 \pm 0.057$ vs $0.677 \pm 0.091$ ) (Fig. 5E, F) and 5 days (Sham vs PBS vs EXO: $0.456 \pm 0.022$ vs $0.737 \pm 0.138$ vs $0.549 \pm 0.052$ ) (Fig. 5G, H) after SCI. It was also observed that P65 fluorescence intensity around the injury site was increased in the SCI group 3 days (Fig. 6A) and 5 days (Fig. 6B) after SCI. Hence, the above results suggested that SCI could activate the ROS-MAPK-NFKB P65 signaling pathway. Additionally, after treatment with DPSC-derived exosomes, increased ROS levels, P-ERK/ERK levels and P65 fluorescence intensity were all reduced compared with those of the PBS group (Figs. 5, 6A, B). Therefore, we learned that DPSC-derived exosomes can inhibit the ROS-MAPK-NFKB P65 signaling pathway in vivo. However, the ROS level, P-ERK/ERK level and P65 fluorescence intensity were still higher than those in the sham group.

\section{DPSC-derived exosomes can protect the injured spinal cord by inhibiting $\mathrm{M} 1$ macrophage polarization}

At 3 days (Fig. 6A) and 5 days (Fig. 6B) after spinal cord injury, the CD86 fluorescence intensity was higher than that in the sham group, indicating more M1 macrophages around the injury site. After treatment with DPSCderived exosomes, the number of M1-polarized macrophages around the injury site was less than that of the PBS-treated group and more than that of the sham group (Fig. 6).

At 28 days after SCI, NF200 fluorescence and NEUN fluorescence were performed. The fluorescence results showed that there were transitional regions between the undamaged area and the scar area in the PBS-treated group (Fig. 7A). There were no or very few neurons in the transitional regions. The transitional regions were smaller or less obvious in the exosome-treated group. The same results were also found by HE staining (Fig. 7B). The results also showed that both the PBS- and exosometreated groups presented complete hind limb paralysis with a BMS score of 0 at 1 day postinjury. At 28 days after $\mathrm{SCI}$, the exosome-treated group had higher BMS scores (PBS vs EXO: $2.333 \pm 1.155$ vs $4.667 \pm 0.577$ ) (Fig. 7C).

\section{Discussion}

Most of the damage that occurs in spinal cord tissue after SCI is exacerbated by secondary damage [14, 48], and ROS play a key role in the secondary injury of SCI. Previous studies have demonstrated that ROS can activate the NLRP3 inflammasome, and inhibiting ROS production can reduce brain injury by downregulating NLRP3 [49-51]. Under normal conditions, the balance of ROS levels is regulated through ROS generation and inactivation. A lesion can break the balance by the depletion of antioxidant systems or the excess production of ROS, resulting in an increase in ROS levels [14]. ROS are commonly thought to be released from activated macrophages and neutrophils in the lesion site [52, 53]. Some studies have suggested that ROS may also trigger neutrophil-mediated inflammation, which is considered to contribute to secondary damage in spinal cord injury $[17,25]$. However, the pathogenic role and mechanism of ROS in neuroinflammation are still not clear. A previous study reported that SCI is associated with inflammation by shifting the microglia/macrophage phenotype [54]. However, ROS levels were markedly increased within $2 \mathrm{~h}$ after injury [19] and occurred earlier than inflammation. We then hypothesized that ROS may trigger M1 macrophage polarization after SCI. The present study demonstrated that M0 macrophages can be shifted to the M1 phenotype after treatment with $\mathrm{H}_{2} \mathrm{O}_{2}$ for $24 \mathrm{~h}$. The macrophage $\mathrm{M} 1$ polarization rate increased with increasing $\mathrm{H}_{2} \mathrm{O}_{2}$ concentration in the culture medium, suggesting that ROS concentration-dependent promotion of M1 macrophage polarization occurred. Hence, we also

\footnotetext{
(See figure on next page.)

Fig. 3 ROS activates macrophages M1 polarization through MAPK-NFkB P65 signaling pathway. $\mathbf{A}$ and $\mathbf{B}$ Raw264.7 cells were treated with $\mathrm{H}_{2} \mathrm{O}_{2}$ or $\mathrm{H}_{2} \mathrm{O}_{2}+$ DPI. M1 macrophages surface expression (CD86) was detected using flow cytometry. $\mathrm{H} 2 \mathrm{O} 2$ could promote M1 macrophage polarization, but DPI had no effect on M1 macrophage polarization induced by H2O2. C and D The ERK1/2 and p-ERK1/2 protein expression in Raw264.7 cells was either investigated. $\mathrm{H} 2 \mathrm{O} 2$ could increase the P-ERK/ERK level and that DPI had no influence on the phosphorylation of ERK in cells cultured with H2O2. E-G P65 protein expression are determined by immunofluorescences and flow cytometry. P65 expression was also increased after $\mathrm{H} 2 \mathrm{O} 2$ treatment for $24 \mathrm{~h}$, and DPI could not suppress the P65 fluorescence increase caused by $\mathrm{H} 2 \mathrm{O} 2 . \mathbf{H}$ and I Raw264.7 cells were treated with $\mathrm{H}_{2} \mathrm{O}_{2}$, $\mathrm{H}_{2} \mathrm{O}_{2}+\mathrm{BAY}$ 11-7082 or $\mathrm{H}_{2} \mathrm{O}_{2}+$ PD98059. J and $\mathbf{K}$ Raw264.7 cells were treated with LPS, LPS + BAY 11-7082 or LPS + PD98059. L-N P65 protein expression are determined by immunofluorescences and flow cytometry. M1 macrophages surface expression (CD86) was detected using using flow cytometry. macrophage M1 polarization caused by both LPS and H2O2 could be suppressed by the P65 inhibitor. PD98059, an inhibitor of MEK, could also inhibit P65 expression and that M1 macrophage polarization was increased by LPS or H2O2. ${ }^{*} p<0.05,{ }^{* * *} p<0.01$
} 

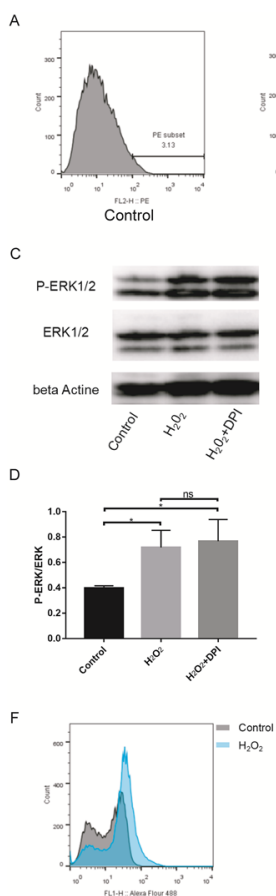

$\mathrm{H}$

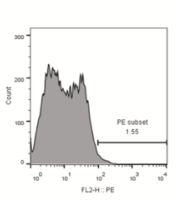

Control

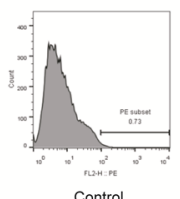

Control
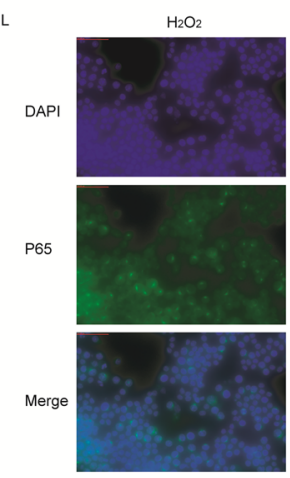

M

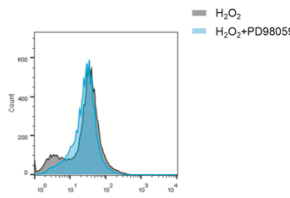

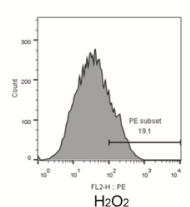
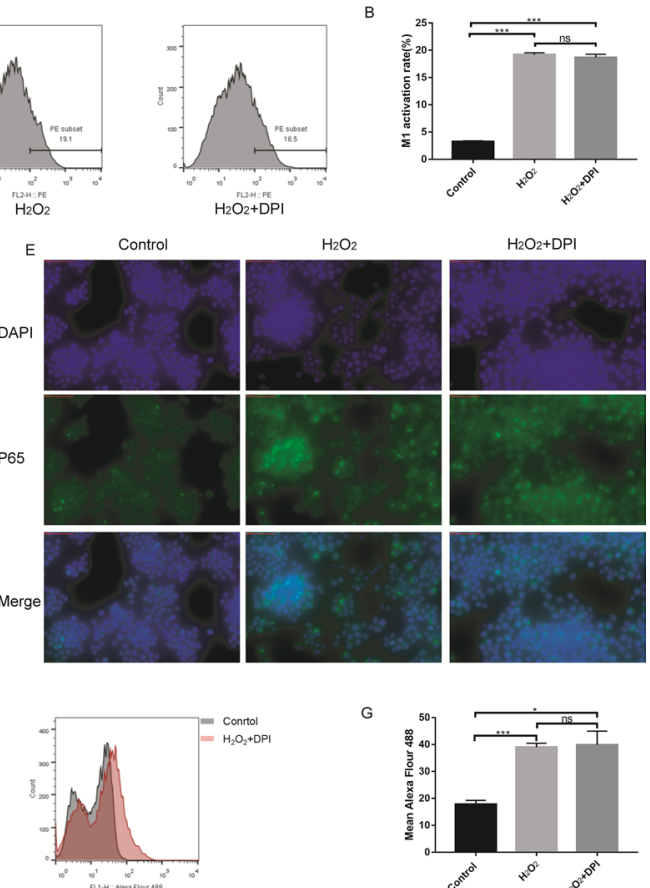

$\mathrm{H}_{2} \mathrm{O}_{2}$

$\mathrm{H}_{2} \mathrm{O}_{2}+\mathrm{DPl}$
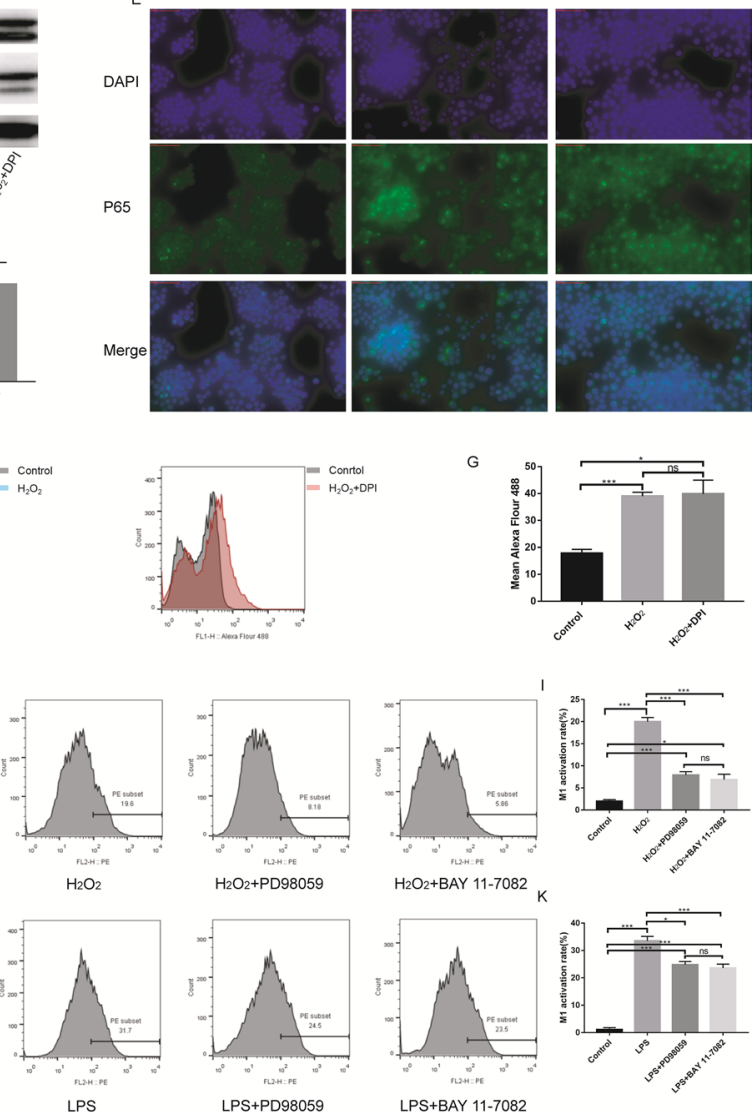

LPS
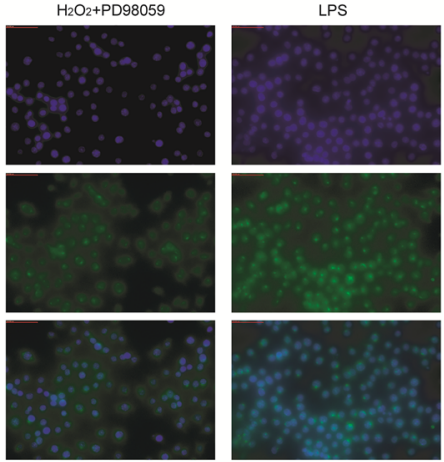

LPS+PD98059
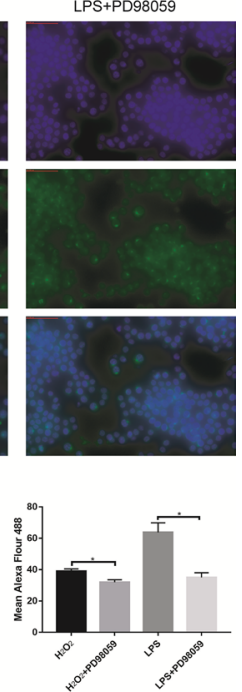

Fig. 3 (See legend on previous page.) 
hypothesized that there was positive feedback between ROS and neuroinflammation after SCI, which may extend the inflammation period and the inflammatory regions. Disrupting the cycle may be a potential effective strategy to reduce secondary damage. Additionally, LPS was also used to treat cells to mimic cell damage. The results also showed that ROS levels were markedly increased within $2 \mathrm{~h}$ after culture with LPS. To investigate whether LPS activates M1 macrophage polarization mainly through ROS, quantitative RT-PCR analysis was performed to determine whether $\mathrm{H}_{2} \mathrm{O}_{2}$ upregulated the expression of iNOS, an M1 macrophage phenotype [44], earlier than LPS. Quantitative RT-PCR analysis revealed that both LPS and $\mathrm{H}_{2} \mathrm{O}_{2}$ upregulated the expression of iNOS at $6 \mathrm{~h}$ after treatment. This suggests that ROS may be just one of the ways LPS induces M1 macrophage polarization (see Fig. 8).

To support the specificity of the findings, we inhibited the production of ROS induced by LPS by DPI, which is a nonselective inhibitor of ROS-producing flavoenzymes. DPI markedly suppressed LPS-induced M1 macrophage polarization, suggesting that ROS play a key role in activating $\mathrm{M} 1$ macrophage polarization after lesion induction. Furthermore, we added $\mathrm{H}_{2} \mathrm{O}_{2}$ to the medium and found that DPI could not suppress the macrophage M1 polarization activation ability of $\mathrm{H}_{2} \mathrm{O}_{2}$ and that the ability of DPI to inhibit macrophage M1 polarization induced by LPS could be offset by $\mathrm{H}_{2} \mathrm{O}_{2}$. This result suggested that after injury, increased ROS can induce M1 macrophage polarization.

Activation of the MAPK signaling pathway plays an important role in the mediation of proinflammatory factors by microglia/macrophages after acute SCI [48]. MAPK is the best characterized oxidation-reduction sensitive signaling pathway, and the increase in ROS production could result in activation of the MAPK pathway [22, 26, 27], which could regulate inflammatory responses [48]. Studies have reported that activating the MAPK signaling pathway can lead to inflammation via downstream activation of the NFKB signaling pathway [55-59]. Hyperphosphorylation of MAPK molecules can activate $\mathrm{NF \kappa B}$ release, and then $\mathrm{NF \kappa B}$ is transferred into the nucleus, further activating inflammatory reactions. The NFkB signaling pathway is a master regulator of a vast repertoire of proinflammatory cytokines [60] and a ROS-sensitive signaling pathway [22]. Macrophages can be activated through the NFkB signaling pathway [61]. Macrophages are major innate immune cells and play a prominent role in the inflammatory process. Hence, we hypothesized that the ROS-MAPK-NFkB P65 signaling pathway may be a potentially targetable pathway for suppressing M1 macrophage polarization. To verify our hypothesis, the expression of t-ERK and p-ERK was determined using WB, and P65 was assessed by immunofluorescence staining. Western blot results showed that $\mathrm{H}_{2} \mathrm{O}_{2}$ could promote ERK phosphorylation, and DPI did not have an inhibitory effect on ERK phosphorylation caused by $\mathrm{H}_{2} \mathrm{O}_{2}$. Immunofluorescence staining results showed that $\mathrm{H}_{2} \mathrm{O}_{2}$ could also cause an increase in P65 fluorescence, while DPI could not effectively suppress an increase in P65 fluorescence. Interestingly, DPI effectively suppressed ERK phosphorylation and P65 immunofluorescence staining caused by LPS. Moreover, a $\mathrm{P} 65$ inhibitor suppressed macrophage M1 polarization caused by $\mathrm{H}_{2} \mathrm{O}_{2}$ and LPS. Additionally, an ERK inhibitor also reduced the macrophage $\mathrm{M} 1$ polarization rate and the P65 fluorescence increase caused by $\mathrm{H}_{2} \mathrm{O}_{2}$ and LPS. Therefore, these results proved our hypothesis that the ROS-MAPK-NFKB P65 signaling pathway was a potentially targetable pathway for suppressing M1 macrophage polarization.

Numerous studies have demonstrated that transplantation of mesenchymal stem cells (MSCs) is an ideal candidate for the cell-based treatment of SCI [62-64]. MSCs protect tissue damage mainly by suppressing inflammation through paracrine mechanisms and promote endogenous repair through stem cell regeneration and differentiation $[10,65,66]$. However, some drawbacks of transplanted stem cells, such as their lower survival rate, immune rejection, cell dedifferentiation and tumor formation, limit their application in treating SCI [10]. Exosomes are small paracrine particles with diameters ranging from 40 to $100 \mathrm{~nm}$ that are secreted by living cells and formed from proteins, signal proteins,

(See figure on next page.)

Fig. 4 Characteristics of DPSCs derived Exosomes. DPSC derived exosomes could inhibit macrophages M1 polarization through MAPK-NFKB P65 signaling pathway in vivo. A Representative images of exosomes are observed under transmission electron microscopy (TEM). Size distribution of extracellular vesicle is measured by nanoparticle tracking analysis (NTA, ZetaView, Particle Metrix Inc., German). Western-blotting analysis of indicated proteins is detected, including CD63, CD9, tubulin, albumin and the MSC marker CD73. B and C Raw264.7 cells were treated with LPS or LPS + EXO for 2, 4, 6 and $24 \mathrm{~h}$. ROS level was detected by using FACS with a flow cytometry. The LPS + Exos group had a lower ROS level than the LPS group. D and E Raw264.7 cells were treated with LPS or LPS + EXO for 24 h. M1 macrophages surface expression (CD86) was detected using using flow cytometry. DPSC-derived exosomes could lower the LPS-induced increase in the M1 polarization rate. F and G The ERK1/2 and p-ERK1/2 protein expression in Raw264.7 cells was either investigated. LPS + Exos group had a lower P-ERK/ERK level than the LPS group. H-J P65 protein expression are determined by immunofluorescences and flow cytometry. DPSC-derived exosomes also inhibited the increase in P65 fluorescence induced by LPS. ${ }^{*} p<0.05,{ }^{* * *} p<0.01$ 

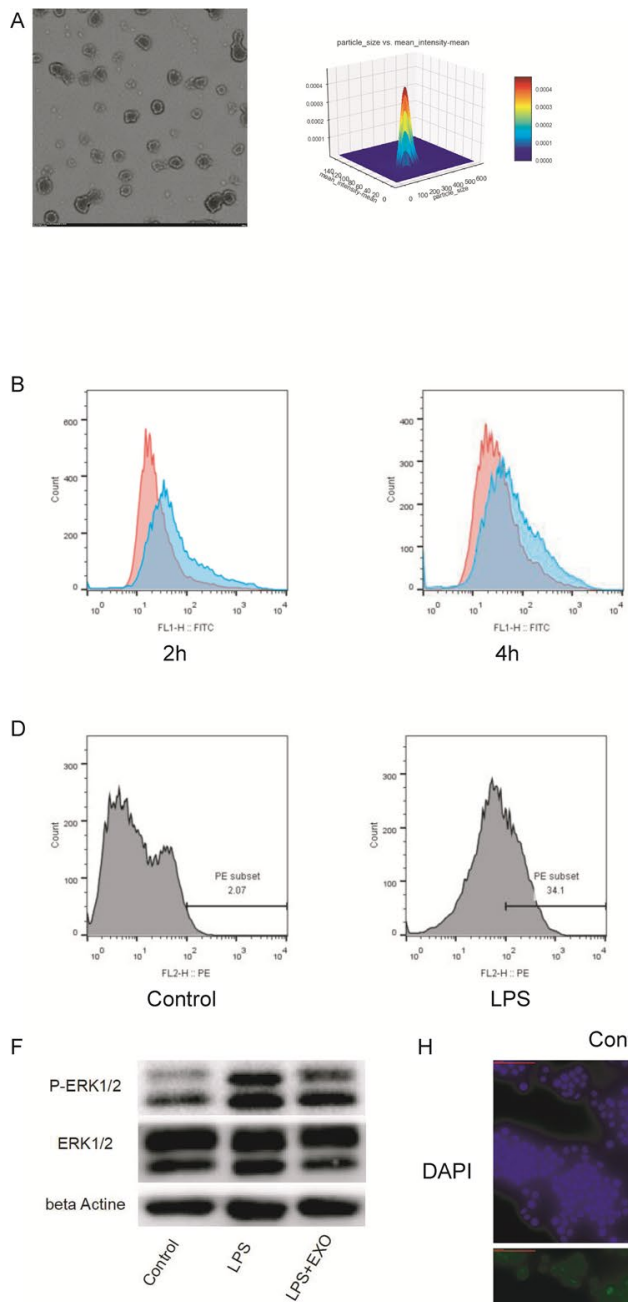

G
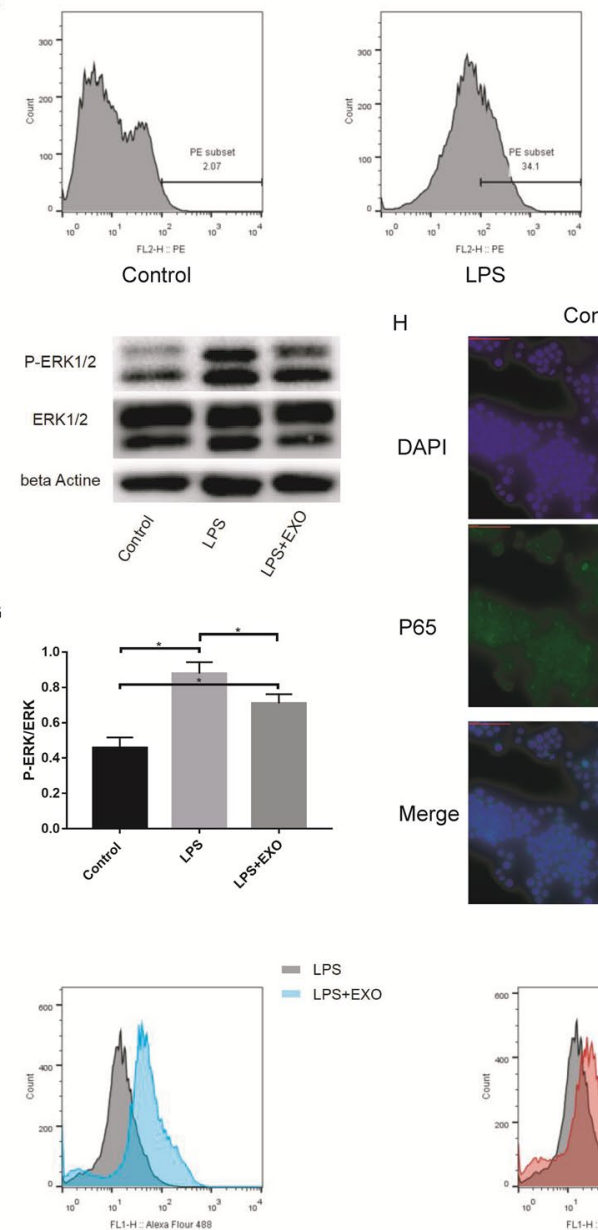
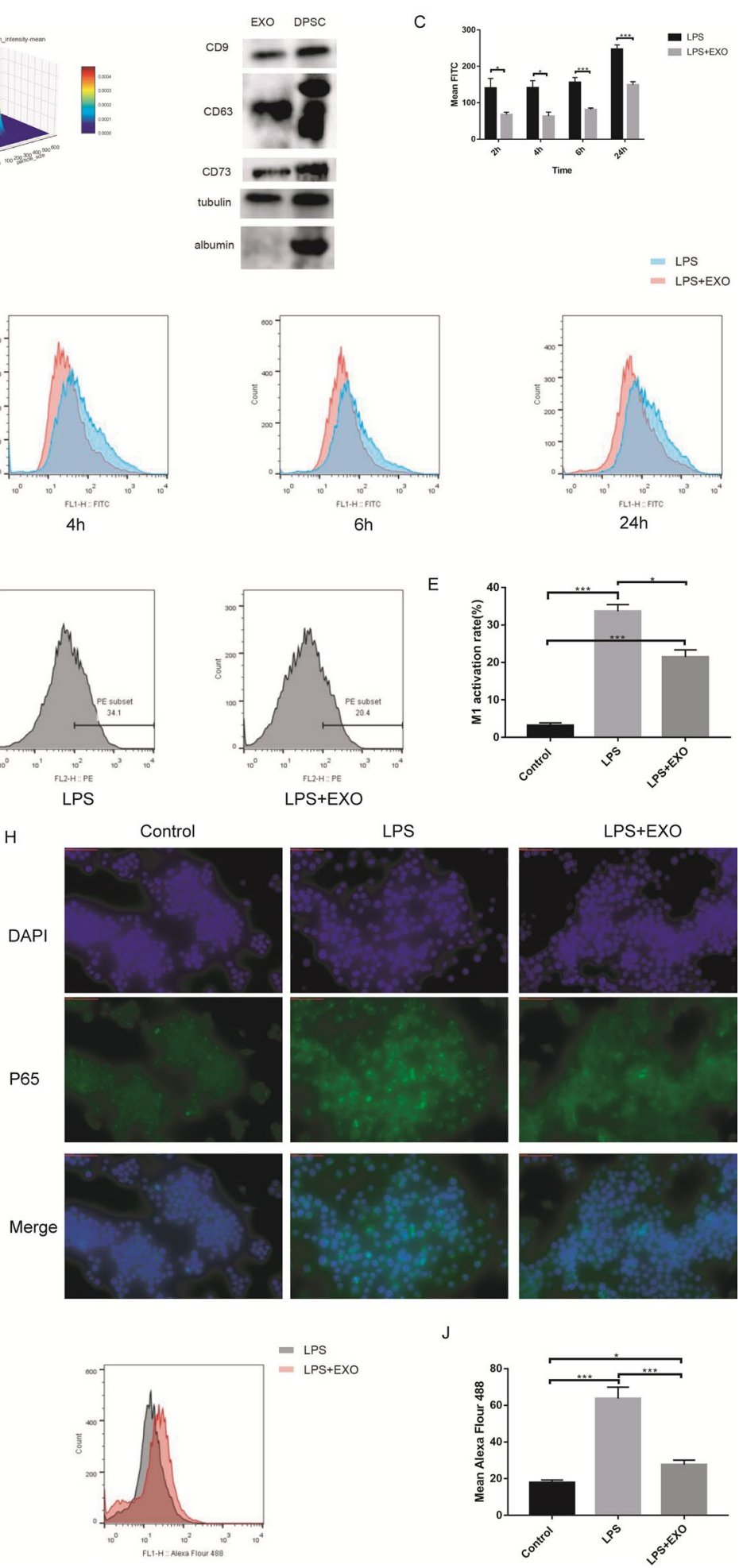

Fig. 4 (See legend on previous page.) 


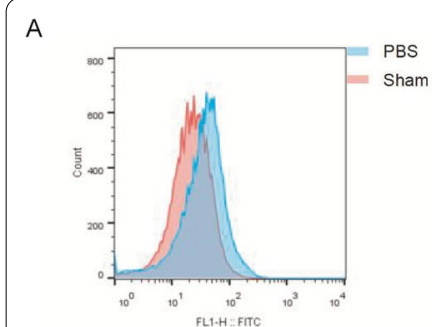

C

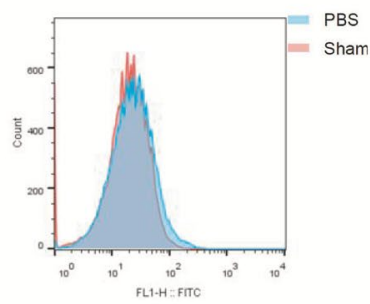

E

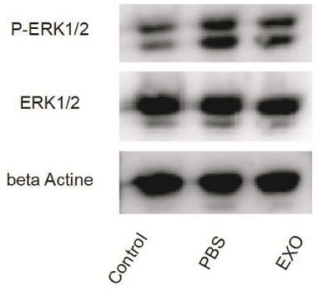

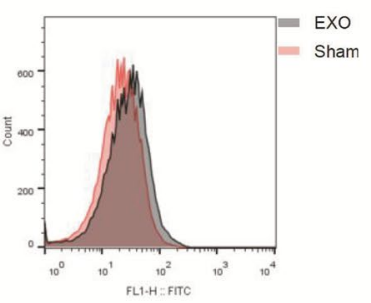
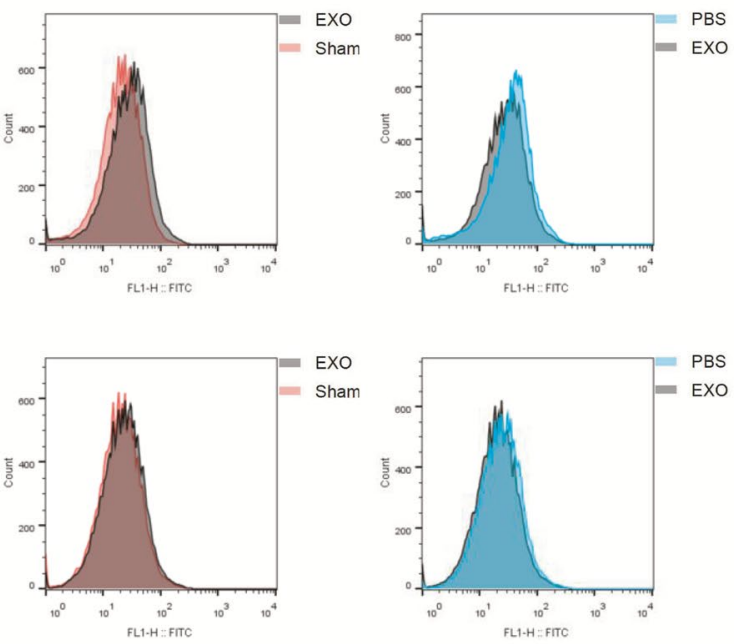

$\mathrm{F}$

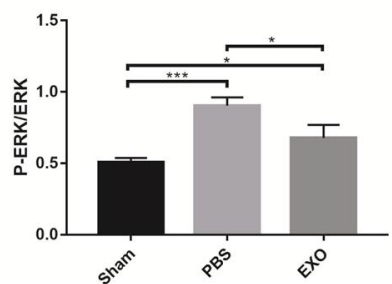

B

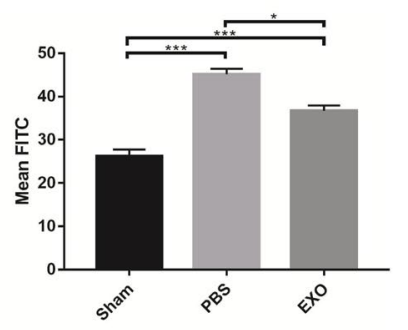

D

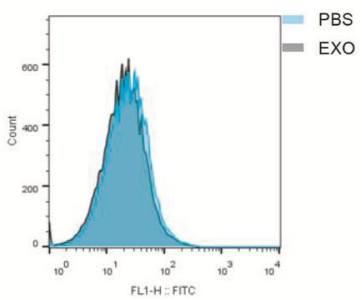

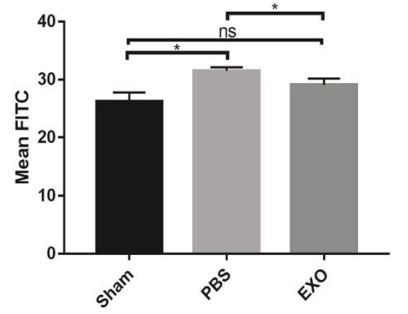

$\mathrm{H}$

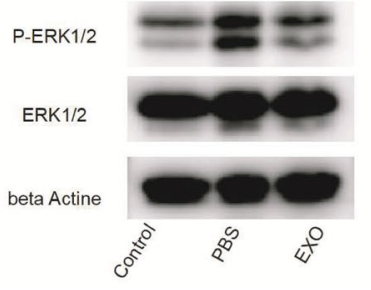

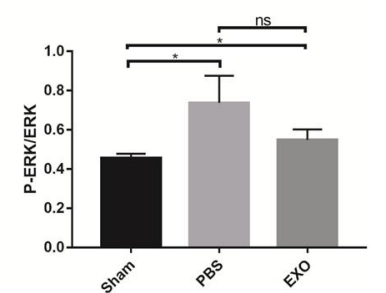

Fig. 5 DPSC derived exosomes can inhibit ROS-MAPK-NFKB P65 signaling pathway in vivo. ROS level was detected by using FACS with a flow cytometry. $\mathbf{A}$ and $\mathbf{B}$ Mice are analyzed at 3 days after injured spinal cord. $\mathbf{C}$ and $\mathbf{D}$ Mice are analyzed at 5 days after injured spinal cord. There was a marked increase in ROS levels in the injured spinal cord at 3 days and 5 days. $\mathbf{E}$ and $\mathbf{F}$ At 3 days, the ERK1/2 and p-ERK1/2 protein expression in spinal tissues was investigated. $\mathbf{G}$ and $\mathbf{H}$ At 5 days, the ERK1/2 and p-ERK1/2 protein expression in spinal tissues was either investigated. There was also a higher P-ERK/ERK level in the SCI group than in the sham group at 3 days and 5 days. ${ }^{*} p<0.05,{ }^{* * *} p<0.01$.

cytoskeletal proteins, and growth factors [29-31]. In the present study, TRPS analysis revealed a diameter of approximately $100 \mathrm{~nm}$. The expression of the exosome markers CD63, CD9, tubulin and the MSC marker CD73 in the DPSC-Exo samples and DPSC proteins was verified by western blot [67]. The protein marker albumin is negative in exosomes [67]. Stem cell-derived exosomes can exercise similar biological roles to stem cells. Additionally, exosomes are nanometer particles and can easily cross the blood-brain barrier (BBB) into spinal tissue, playing a therapeutic role. Many studies have demonstrated that stem cell-derived exosomes can reduce the ROS level in injured tissue and reduce M1 macrophage polarization in an SCI model [10, 36, 37]. Liu et al. reported that exosomes derived from mesenchymal stem cells could shift microglial M1/M2 polarization via miR216a-5p [10]. Hong et al. reported that exosomes from adipose-derived stem cells could attenuate UVB-induced ROS [36]. Shen et al. reported that exosomes from adipose-derived stem cells could alleviate inflammation and oxidative stress by regulating the $\mathrm{Nrf} / \mathrm{HO}-1$ axis in macrophages [37]. However, no study has investigated the relationship between increased ROS levels and M1 macrophage polarization in an SCI model. The present study demonstrated that ROS can induce M1 macrophage polarization. Hence, we hypothesized that exosomes may reduce $\mathrm{M} 1$ macrophage polarization through the ROSMAPK-NFKB P65 signaling pathway in an SCI model. In vitro, DPSC-derived exosomes markedly reduced the ROS level and the M1 macrophage polarization rate of damaged cells. Western blot results showed that DPSCderived exosomes could also inhibit ERK phosphorylation and P65 signaling pathway activation. To further confirm the findings, an SCI model was established. We observed that exosomes could markedly reduce ROS levels and the recruitment and invasion of M1 macrophages to lesions at 3 and 5 days after SCI, and activation of the ROS-MAPK-NFkB P65 signaling pathway was also suppressed. At 28 days after $\mathrm{SCI}$, transitional regions between the undamaged area and the scar area were noted, and there were no or very few neurons in the transitional regions. Compared with the PBS-treated group, the transitional regions were smaller or less obvious in the exosome-treated group. The Basso Mouse Scale score 


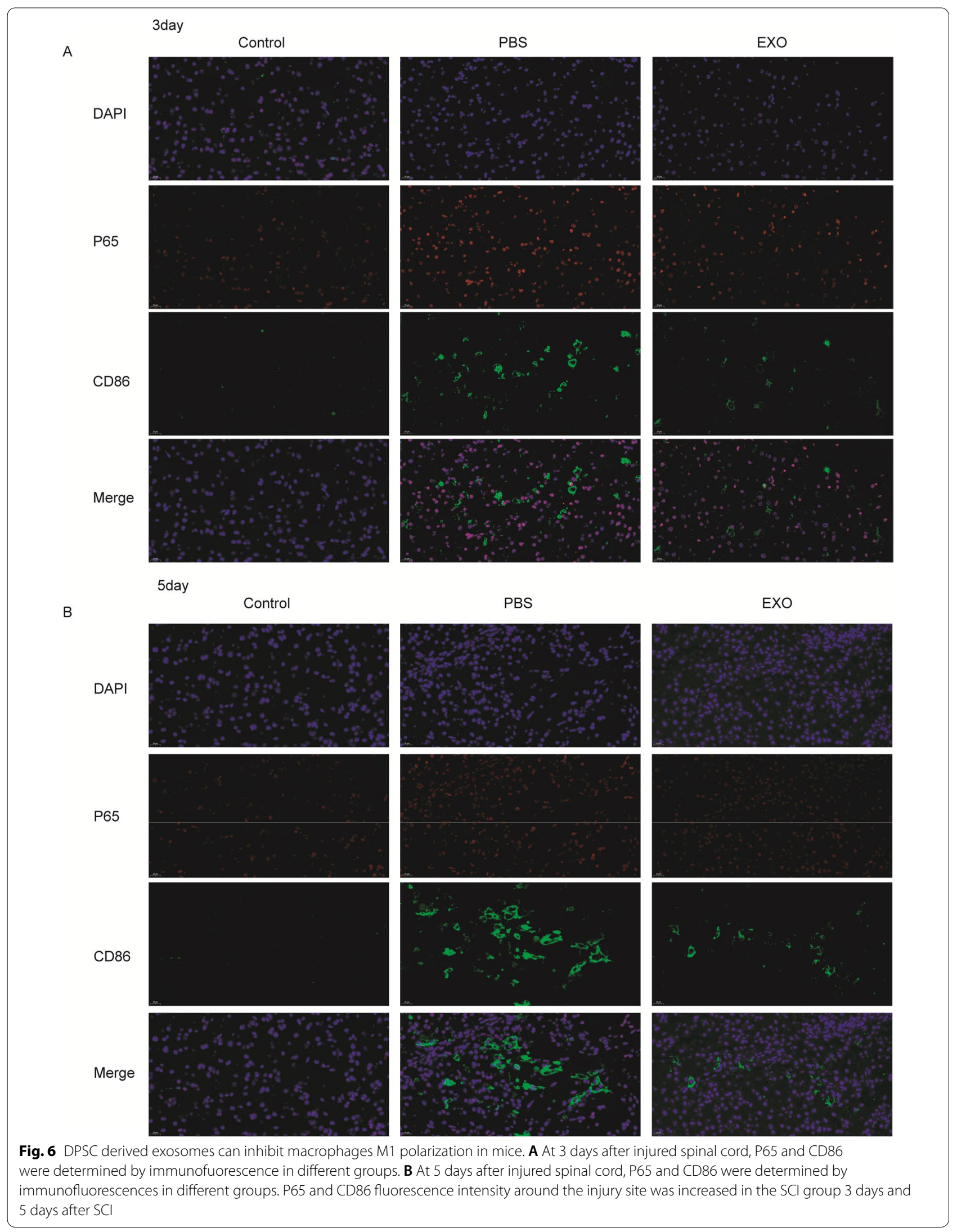




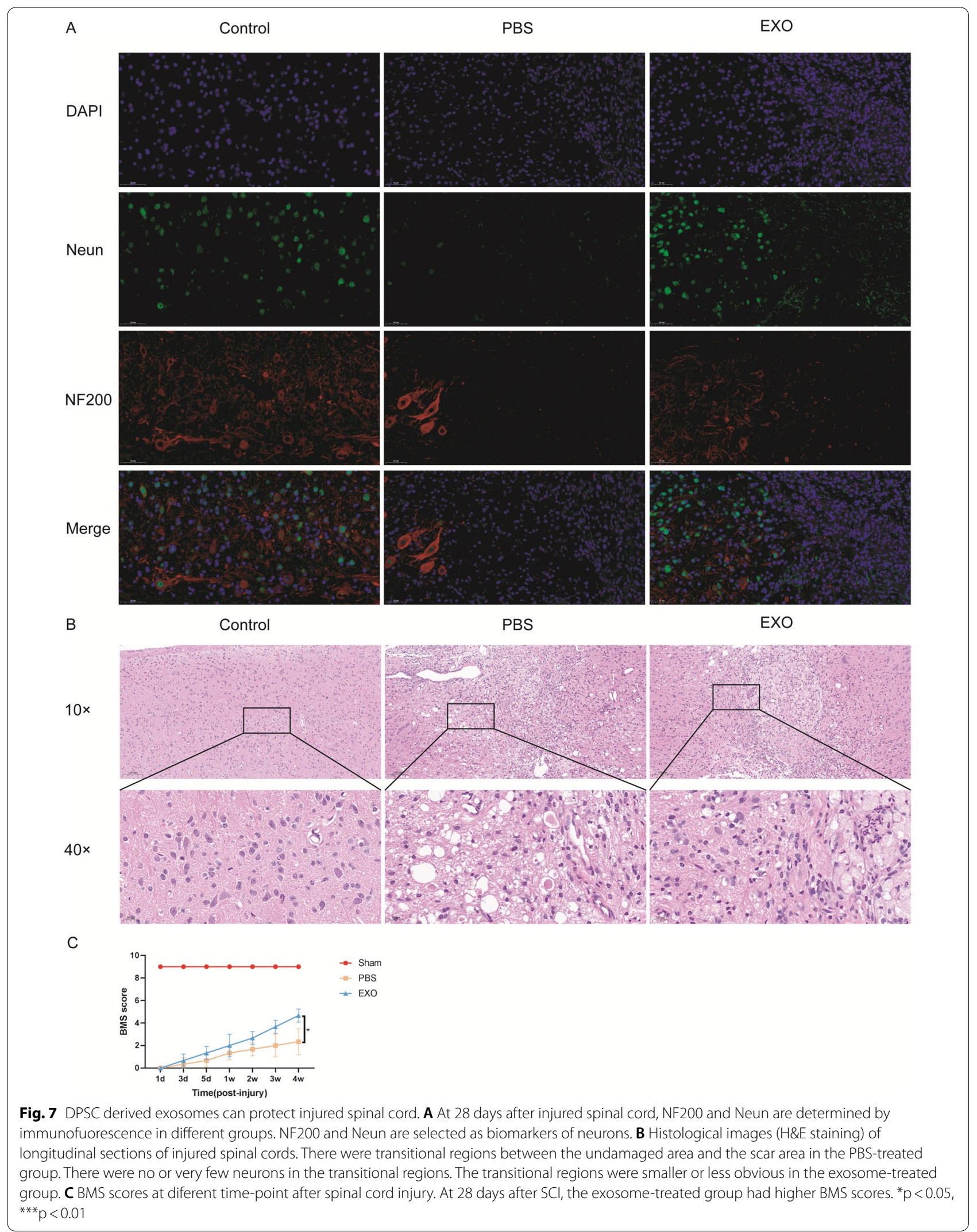




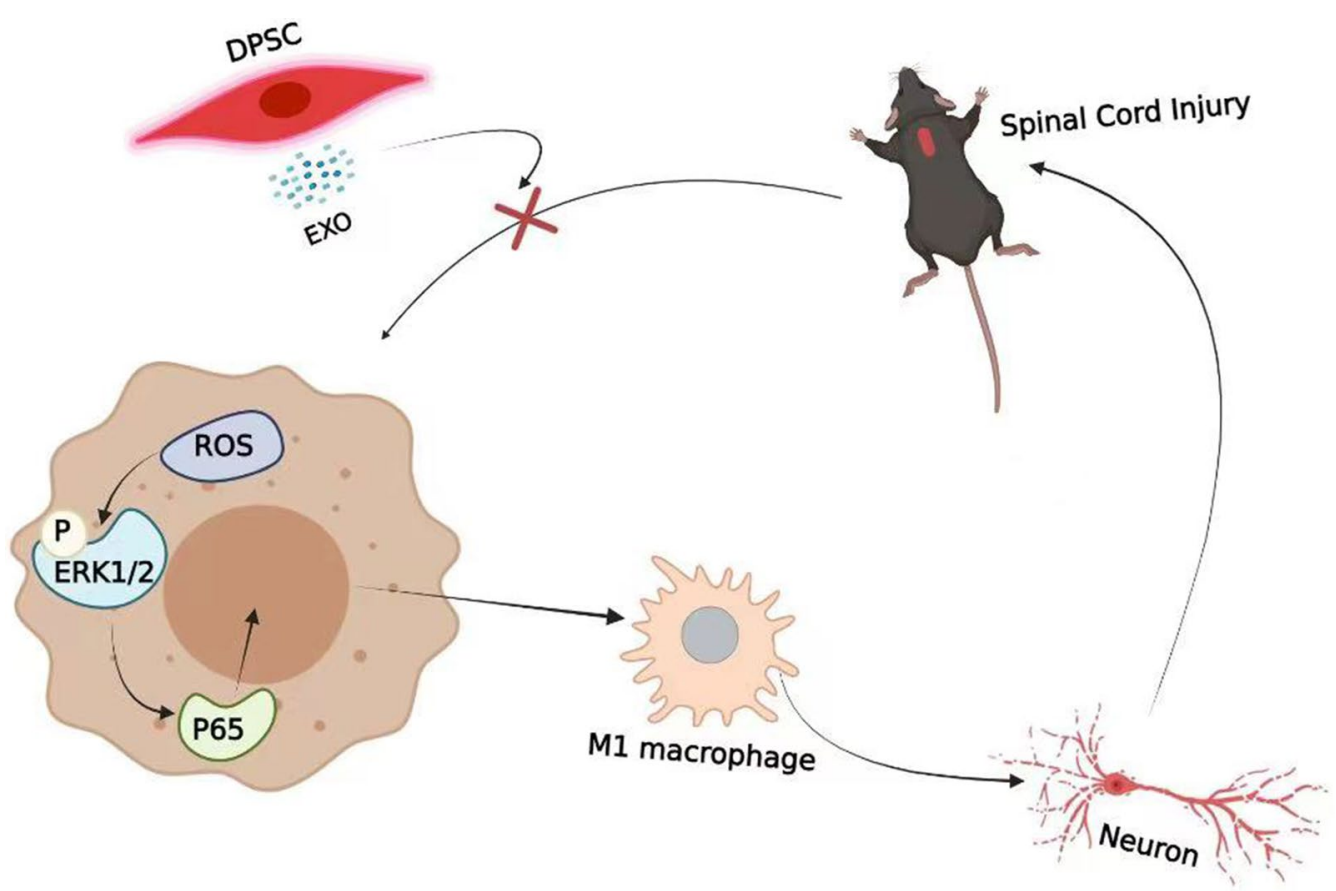

Fig. 8 Schematic diagram showing the effects of dental pulp stem cells-derived exosomes on SCI

of the exosome-treated group was significantly higher than that of the PBS-treated group. These results demonstrated that DPSC-derived exosomes could reduce neurological impairment by reducing macrophage M1 polarization through suppressing ROS-MAPK-NFkB P65 signaling pathway activation.

\section{Conclusion}

In summary, this study revealed that the ROS-MAPKNFkB P65 signaling pathway was a potentially targetable pathway for treating SCI. DPSC-derived exosomes could attenuate the inflammatory response and reduce neurological impairment by reducing macrophage M1 polarization through suppressing ROS-MAPK-NFkB P65 signaling pathway activation.

\section{Supplementary Information}

The online version contains supplementary material available at https://doi. org/10.1186/s12951-022-01273-4.

Additional file 1: Figure S1. The surface molecule expression profiles and multilineage differentiation of MSCs. A Adipogenesis ability of DPSCS after induction. B Osteogenesis ability of DPSCs after induction. C The surface molecule expression of MSCs.

Additional file 2: Figure S2. A Higher $\mathrm{H} 2 \mathrm{O} 2$ concentration (1 mMol/L) reached toxic level. B Both LPS and $\mathrm{H} 2 \mathrm{O} 2$ can induce the expression of CD80 (A marker of M1 macrophages).

\section{Acknowledgements}

Chao Liu, Fanqi Hu, Genlong Jiao and Yue Guo contribute equally to the study. Xuesong Zhang; Hua Wang and Zhizhong Li contribute equally to the study. We all thank Haitao Du for facilitating us in the course of the trial, and also thank the reviewers for their professional and valuable advice.

\section{Authors' contributions}

$\mathrm{CL}, \mathrm{FH}, \mathrm{GJ}$ and $\mathrm{YG}$ contribute equally. Manuscript writing, data analysis and interpretation. Provision of study material or patients. PZ: data analysis and interpretation. YZ, ZZ and JY: collection and/or assembly of data. YY: collection and/or assembly of data. XZ; HW and ZL: conception and design, financial support. All authors have read and approved the final manuscript.

\section{Declarations}

\section{Ethics approval and consent to participate}

Impacted human wisdom teeth were collected at the Dental Clinic of Beijing Stomatological Hospital under approved guidelines (BSH [2015] D-15). All patients have provided written informed consents to participate. All animal experiments were performed under protocols approved by the Institutional Animal Care and Use Committee of the Beijing Institute of Radiation Medicine (IACUC-DWZX-2020-717).

\section{Consent for publication}

All the authors agree to publish this study in the Journal of Nanobiotechnology.

The data and material are available.

\section{Competing interests}

The authors declare no potential conflicts of interest.

Received: 27 September 2021 Accepted: 17 January 2022

Published online: 02 February 2022 


\section{References}

1. Dutta D, Khan N, Wu J, Jay SM. Extracellular vesicles as an emerging frontier in spinal cord injury pathobiology and therapy. Trends Neurosci. 2021;44(6):492-506. https://doi.org/10.1016/j.tins.2021.01.003.

2. Li L, Zhang Y, Mu J, et al. Transplantation of human mesenchymal stemcell-derived exosomes immobilized in an adhesive hydrogel for effective treatment of spinal cord injury. Nano Lett. 2020;20(6):4298-305. https:// doi.org/10.1021/acs.nanolett.0c00929.

3. Guo S, Perets N, Betzer O, et al. Intranasal delivery of mesenchymal stem cell derived exosomes loaded with phosphatase and tensin homolog siRNA repairs complete spinal cord injury. ACS Nano. 2019;13(9):1001528. https://doi.org/10.1021/acsnano.9b01892.

4. Kim HY, Kumar H, Jo MJ, et al. Therapeutic efficacy-potentiated and diseased organ-targeting nanovesicles derived from mesenchymal stem cells for spinal cord injury treatment. Nano Lett. 2018;18(8):4965-75. https://doi.org/10.1021/acs.nanolett.8b01816.

5. Xu P, Zhang F, Chang MM, et al. (2021) Recruitment of $y \delta T$ cells to the lesion via the CCL2/CCR2 signaling after spinal cord injury. J Neuroinflammation. 2021;18(1):64. https://doi.org/10.1186/s12974-021-02115-0.

6. Rahimi-Movaghar $\mathrm{V}$, Sayyah MK, Akbari H, et al. Epidemiology of traumatic spinal cord injury in developing countries: a systematic review. Neuroepidemiology. 2013;41(2):65-85. https://doi.org/10.1159/00035 0710

7. Fitzharris M, Cripps RA, Lee BB. Estimating the global incidence of traumatic spinal cord injury. Spinal Cord. 2014;52(2):117-22. https://doi.org/ 10.1038/sc.2013.135.

8. Ahuja CS, Wilson JR, Nori S, et al. Traumatic spinal cord injury. Nat Rev Dis Primers. 2017;3:17018. https://doi.org/10.1038/nrdp.2017.18.

9. Jain NB, Ayers GD, Peterson EN, Harris MB, Morse L, O'Connor KC, Garshick E. Traumatic spinal cord injury in the United States.

10. Liu W, Rong Y, Wang J, et al. Exosome-shuttled miR-216a-5p from hypoxic preconditioned mesenchymal stem cells repair traumatic spinal cord injury by shifting microglial M1/M2 polarization. J Neuroinflammation. 2020;17(1):47. https://doi.org/10.1186/s12974-020-1726-7.

11. Ropper $A E$, Ropper $A H$. Acute spinal cord compression. N Engl J Med. 2017;376(14):1358-69. https://doi.org/10.1056/NEJMra1516539.

12. Varma AK, Das A, Wallace $G$ 4th, et al. Spinal cord injury: a review of current therapy, future treatments, and basic science frontiers. Neurochem Res. 2013;38(5):895-905. https://doi.org/10.1007/s11064-013-0991-6.

13. Sun $\mathrm{G}$, Yang $\mathrm{S}, \mathrm{Cao} \mathrm{G}$, et al. $\gamma \delta \mathrm{T}$ cells provide the early source of IFN- $\gamma$ to aggravate lesions in spinal cord injury. J Exp Med. 2018;215(2):521-35. https://doi.org/10.1084/jem.20170686.

14. Lee YS, Sindhu RK, Lin CY, Ehdaie A, Lin VW, Vaziri ND. Effects of nerve graft on nitric oxide synthase, NAD(P)H oxidase, and antioxidant enzymes in chronic spinal cord injury. Free Radic Biol Med. 2004;36(3):330-9. https://doi.org/10.1016/j.freeradbiomed.2003.11.006.

15. Hall ED, Braughler JM. Central nervous system trauma and stroke. II. Physiological and pharmacological evidence for involvement of oxygen radicals and lipid peroxidation. Free Radic Biol Med. 1989:6(3):303-13. https://doi.org/10.1016/0891-5849(89)90057-9.

16. Siesjö BK, Agardh CD, Bengtsson F. Free radicals and brain damage. Cerebrovasc Brain Metab Rev. 1989;1(3):165-211.

17. Juurlink $\mathrm{BH}$, Paterson PG. Review of oxidative stress in brain and spinal cord injury: suggestions for pharmacological and nutritional management strategies. J Spinal Cord Med. 1998;21(4):309-34. https://doi.org/10. 1080/10790268.1998.11719540.

18. Aksenova M, Butterfield DA, Zhang SX, Underwood M, Geddes JW. Increased protein oxidation and decreased creatine kinase BB expression and activity after spinal cord contusion injury. J Neurotrauma. 2002;19(4):491-502. https://doi.org/10.1089/08977150252932433.

19. Hervera A, De Virgiliis F, Palmisano I, et al. Publisher Correction: Reactive oxygen species regulate axonal regeneration through the release of exosomal NADPH oxidase 2 complexes into injured axons. Nat Cell Biol. 2018:20(9):1098. https://doi.org/10.1038/s41556-018-0063-x.

20. Yang MC, Zhang HZ, Wang Z, You FL, Wang YF. The molecular mechanism and effect of cannabinoid-2 receptor agonist on the blood-spinal cord barrier permeability induced by ischemia-reperfusion injury. Brain Res. 2016;1636:81-92. https://doi.org/10.1016/j.brainres.2016.01.047.

21. Scott TL, Rangaswamy S, Wicker CA, Izumi T. Repair of oxidative DNA damage and cancer: recent progress in DNA base excision repair.
Antioxid Redox Signal. 2014;20(4):708-26. https://doi.org/10.1089/ars. 2013.5529.

22. Sano M, Fukuda K, Sato T, et al. ERK and p38 MAPK, but not NF-kappaB, are critically involved in reactive oxygen species-mediated induction of IL-6 by angiotensin II in cardiac fibroblasts. Circ Res. 2001;89(8):661-9. https://doi.org/10.1161/hh2001.098873.

23. Abdelhamid HN. Zeolitic imidazolate frameworks (ZIF-8) for biomedical applications: a review. Curr Med Chem. 2021;28(34):7023-75. https://doi. org/10.2174/0929867328666210608143703.

24. Abolghasem AK, Shaghayegh HJ, Mohsen A, Amir R. Recent advances in nanomaterials development for nanomedicine and cancer. ACS Appl Bio Mater. 2021;4(8):5908-25. https://doi.org/10.1021/acsabm.1c00591.

25. Dirnagl U, ladecola C, Moskowitz MA. Pathobiology of ischaemic stroke: an integrated view. Trends Neurosci. 1999;22(9):391-7. https://doi.org/10. 1016/s0166-2236(99)01401-0

26. Baas AS, Berk BC. Differential activation of mitogen-activated protein kinases by $\mathrm{H} 2 \mathrm{O} 2$ and $\mathrm{O} 2$ - in vascular smooth muscle cells. Circ Res. 1995;77(1):29-36. https://doi.org/10.1161/01.res.77.1.29.

27. Ushio-Fukai M, Alexander RW, Akers M, Griendling KK. p38 Mitogenactivated protein kinase is a critical component of the redox-sensitive signaling pathways activated by angiotensin II: role in vascular smooth muscle cell hypertrophy. J Biol Chem. 1998;273:15022-9.

28. Jiang $R$, Wang NP, Tanaka KA, et al. Factor Xa induces tissue factor expression in endothelial cells by P44/42 MAPK and NF-kB-dependent pathways. J Surg Res. 2011;169(2):319-27. https://doi.org/10.1016/j.jss. 2010.01.041.

29. Morishita M, Takahashi Y, Nishikawa M, Takakura Y. Pharmacokinetics of exosomes-an important factor for elucidating the biological roles of exosomes and for the development of exosome-based therapeutics. J Pharm Sci. 2017;106(9):2265-9. https://doi.org/10.1016/j.xphs.2017.02. 030.

30. Raposo G, Stoorvogel W. Extracellular vesicles: exosomes, microvesicles, and friends. J Cell Biol. 2013;200(4):373-83. https://doi.org/10.1083/jcb. 201211138.

31. Théry C, Ostrowski M, Segura E. Membrane vesicles as conveyors of immune responses. Nat Rev Immunol. 2009;9(8):581-93. https://doi.org/ 10.1038/nri2567.

32. Doeppner TR, Herz J, Görgens A, et al. Extracellular vesicles improve poststroke neuroregeneration and prevent postischemic immunosuppression. Stem Cells Transl Med. 2015;4(10):1131-43. https://doi.org/10.5966/ sctm.2015-0078.

33. Lankford KL, Arroyo EJ, Nazimek K, Bryniarski K, Askenase PW, Kocsis JD. Intravenously delivered mesenchymal stem cell-derived exosomes target M2-type macrophages in the injured spinal cord. PLOS ONE. 2018;13(1): e0190358. https://doi.org/10.1371/journal.pone.0190358.

34. de Rivero Vaccari JP, Brand F 3rd, Adamczak S, et al. Exosome-mediated inflammasome signaling after central nervous system injury. J Neurochem. 2016;136(Suppl 1(0 1)):39-48. https://doi.org/10.1111/jnc.13036.

35. Rani S, Ryan AE, Griffin MD, Ritter T. Mesenchymal stem cell-derived extracellular vesicles: toward cell-free therapeutic applications. Mol Ther. 2015;23(5):812-23. https://doi.org/10.1038/mt.2015.44.

36. Hong Y, Sun Y, Rong X, Li D, Lu Y, Ji Y. Exosomes from adipose-derived stem cells attenuate UVB-induced apoptosis, ROS, and the Ca2+ level in HLEC cells. Exp Cell Res. 2020;396(2): 112321. https://doi.org/10.1016/j. yexcr.2020.112321.

37. Shen $K$, Jia $Y$, Wang $X$, et al. Exosomes from adipose-derived stem cells alleviate the inflammation and oxidative stress via regulating $\mathrm{Nrf} / \mathrm{HO}-1$ axis in macrophages. Free Radic Biol Med. 2021;165:54-66. https://doi. org/10.1016/j.freeradbiomed.2021.01.023.

38. Ji L, Bao L, Gu Z, et al. Comparison of immunomodulatory properties of exosomes derived from bone marrow mesenchymal stem cells and dental pulp stem cells. Immunol Res. 2019;67(4-5):432-42. https://doi. org/10.1007/s12026-019-09088-6.

39. Li S, Luo L, He Y, et al. Dental pulp stem cell-derived exosomes alleviate cerebral ischaemia-reperfusion injury through suppressing inflammatory response. Cell Prolif. 2021;54(8): e13093. https://doi.org/10.1111/cpr. 13093.

40. Zhu S, Ying Y, He Y, et al. Hypoxia response element-directed expression of bFGF in dental pulp stem cells improve the hypoxic environment by targeting pericytes in SCl rats. Bioact Mater. 2021;6(8):2452-66. https:// doi.org/10.1016/j.bioactmat.2021.01.024. 
41. Luo L, He Y, Wang $X$, et al. Potential roles of dental pulp stem cells in neural regeneration and repair. Stem Cells Int. 2018;2018:1731289. https:// doi.org/10.1155/2018/1731289.

42. Brown GC. Mechanisms of inflammatory neurodegeneration: iNOS and NADPH oxidase. Biochem Soc Trans. 2007;35(Pt 5):1119-21. https://doi. org/10.1042/BST0351119.

43. Bellora F, Castriconi R, Dondero A, et al. The interaction of human natural killer cells with either unpolarized or polarized macrophages results in different functional outcomes. Proc Natl Acad Sci USA. 2010;107(50):21659-64. https://doi.org/10.1073/pnas.1007654108.

44. Sun G, Li G, Li D, et al. huCMSC derived exosomes promote functional recovery in spinal cord injury mice via attenuating inflammation. Mater Sci Eng C Mater Biol Appl. 2018;89:194-204. https://doi.org/10.1016/j. msec.2018.04.006.

45. Kong F, Shi X, Xiao F, et al. Transplantation of hepatocyte growth factormodified dental pulp stem cells prevents bone loss in the early phase of ovariectomy-induced osteoporosis. Hum Gene Ther. 2018;29(2):271-82. https://doi.org/10.1089/hum.2017.091.

46. Ma SF, Chen YJ, Zhang JX, et al. Adoptive transfer of M2 macrophages promotes locomotor recovery in adult rats after spinal cord injury. Brain Behav Immun. 2015;45:157-70. https://doi.org/10.1016/j.bbi.2014.11.007.

47. Basso DM, Fisher LC, Anderson AJ, Jakeman LB, McTigue DM, Popovich PG. Basso mouse scale for locomotion detects differences in recovery after spinal cord injury in five common mouse strains. J Neurotrauma. 2006;23(5):635-59. https://doi.org/10.1089/neu.2006.23.635.

48. Liu Z, Yao X, Jiang W, et al. Advanced oxidation protein products induce microglia-mediated neuroinflammation via MAPKs-NF-kB signaling pathway and pyroptosis after secondary spinal cord injury. J Neuroinflammation. 2020;17(1):90. https://doi.org/10.1186/s12974-020-01751-2.

49. Raju U, Gumin GJ, Tofilon PJ. Radiation-induced transcription factor activation in the rat cerebral cortex. Int J Radiat Biol. 2000;76(8):1045-53. https://doi.org/10.1080/09553000050111514.

50. Sun W, Zeng C, Liu S, et al. Ageratina adenophora induces mice hepatotoxicity via ROS-NLRP3-mediated pyroptosis. Sci Rep. 2018;8(1):16032. https://doi.org/10.1038/s41598-018-34492-7.

51. Alfonso-Loeches S, Ureña-Peralta JR, Morillo-Bargues MJ, Oliver-De La Cruz J, Guerri C. Role of mitochondria ROS generation in ethanol-induced NLRP3 inflammasome activation and cell death in astroglial cells. Front Cell Neurosci. 2014;8:216. https://doi.org/10.3389/fncel.2014.00216.

52. Hackel D, Pflücke $D$, Neumann $A$, et al. The connection of monocytes and reactive oxygen species in pain. PLoS ONE. 2013;8(5): e63564. https://doi. org/10.1371/journal.pone.0063564.

53. Pflücke D, Hackel D, Mousa SA, et al. The molecular link between C-Cchemokine ligand 2-induced leukocyte recruitment and hyperalgesia. J Pain. 2013;14(9):897-910. https://doi.org/10.1016/j.jpain.2013.02.012.

54. Beattie MS. Inflammation and apoptosis: linked therapeutic targets in spinal cord injury. Trends Mol Med. 2004;10(12):580-3. https://doi.org/10. 1016/j.molmed.2004.10.006

55. Ramalingam P, Poulos MG, Lazzari E, et al. Chronic activation of endothelial MAPK disrupts hematopoiesis via NFKB dependent inflammatory stress reversible by SCGF. Nat Commun. 2020;11(1):666. https://doi.org/ 10.1038/s41467-020-14478-8.

56. Sánchez Á, Relaño C, Carrasco A, et al. Map3k8 controls granulocyte colony-stimulating factor production and neutrophil precursor proliferation in lipopolysaccharide-induced emergency granulopoiesis. Sci Rep. 2017;7(1):5010. https://doi.org/10.1038/s41598-017-04538-3.

57. Roth Flach RJ, Skoura A, Matevossian A, et al. Endothelial protein kinase MAP4K4 promotes vascular inflammation and atherosclerosis. Nat Commun. 2015;6:8995. https://doi.org/10.1038/ncomms9995.

58. Baker RG, Hayden MS, Ghosh S. NF-kB, inflammation, and metabolic disease. Cell Metab. 2011;13(1):11-22. https://doi.org/10.1016/j.cmet.2010. 12.008 .

59. Bottero V, Withoff S, Verma IM. NF-kappaB and the regulation of hematopoiesis. Cell Death Differ. 2006;13(5):785-97. https://doi.org/10.1038/sj. cdd.4401888.

60. Xiao L, Liu Y, Wang N. New paradigms in inflammatory signaling in vascular endothelial cells. Am J Physiol Heart Circ Physiol. 2014;306(3):H317-25. https://doi.org/10.1152/ajpheart.00182.2013.

61. Liu G, Fan G, Guo G, et al. FK506 attenuates the inflammation in rat spinal cord injury by inhibiting the activation of NF-KB in microglia cells. Cell Mol Neurobiol. 2017;37(5):843-55. https://doi.org/10.1007/ s10571-016-0422-8

62. Chopp M, Zhang XH, Li Y, et al. Spinal cord injury in rat: treatment with bone marrow stromal cell transplantation. NeuroReport. 2000;11(13):3001-5. https://doi.org/10.1097/00001756-200009110-00035.

63. Assinck P, Duncan GJ, Hilton BJ, Plemel JR, TetzlaffW. Cell transplantation therapy for spinal cord injury. Nat Neurosci. 2017;20(5):637-47. https:// doi.org/10.1038/nn.4541.

64. Gong Z, Xia K, Xu A, et al. Stem cell transplantation: a promising therapy for spinal cord injury. Curr Stem Cell Res Ther. 2020;15(4):321-31. https:// doi.org/10.2174/1574888X14666190823144424.

65. Kalladka D, Muir KW. Brain repair: cell therapy in stroke. Stem Cells Cloning. 2014;7:31-44. https://doi.org/10.2147/SCCAA.S38003.

66. Torres-Espín A, Hernández J, Navarro X. Gene expression changes in the injured spinal cord following transplantation of mesenchymal stem cells or olfactory ensheathing cells. PLoS ONE. 2013;8(10): e76141. https://doi. org/10.1371/journal.pone.0076141.

67. Théry C, Witwer KW, Aikawa E, et al. Minimal information for studies of extracellular vesicles 2018 (MISEV2018): a position statement of the International Society for Extracellular Vesicles and update of the MISEV2014 guidelines. J Extracell Vesicles. 2018;7(1):1535750. https://doi.org/10. 1080/20013078.2018.1535750.

\section{Publisher's Note}

Springer Nature remains neutral with regard to jurisdictional claims in published maps and institutional affiliations.

Ready to submit your research? Choose BMC and benefit from:

- fast, convenient online submission

- thorough peer review by experienced researchers in your field

- rapid publication on acceptance

- support for research data, including large and complex data types

- gold Open Access which fosters wider collaboration and increased citations

- maximum visibility for your research: over $100 \mathrm{M}$ website views per year

At BMC, research is always in progress.

Learn more biomedcentral.com/submissions 